\title{
Geochemistry and Geochronology of Peraluminous High-K Granitic Leucosomes of Yaoundé Series (Cameroon): Evidence for a Unique Pan-African Magmatism and Melting Event in North Equatorial Fold Belt
}

\author{
Timoleon Ngnotue ${ }^{1,2^{*}}$, Ganno Sylvestre ${ }^{2}$, Nzenti Jean Paul², Schulz Bernhard ${ }^{3}$, \\ Tchaptchet Tchato Depesquidoux I ${ }^{2}$, Suh Cheo Emmanuel ${ }^{4}$ \\ ${ }^{1}$ Department of Geology, University of Dschang, Dschang, Cameroon \\ ${ }^{2}$ Department of Earth Sciences, University of Yaoundé I, Messa, Yaoundé \\ ${ }^{3}$ Institut für Mineralogie, Technische Universität Bergakademie, Freiberg, Germany \\ ${ }^{4}$ Department of Geology, University of Buea, Buea, Cameroon \\ Email: *tngnotue@yahoo.fr, lpgsdor@yahoo.com
}

Received January 2, 2012; revised March 6, 2012; accepted May 5, 2012

\begin{abstract}
Geochemical and geochronological studies have been carry out on the leucosomes of Yaounde series with the aims to identify the magma sources and to indicate their production periods and emplacement within the formations of the Pan-African North-Equatorial Fold Belt (PANEFB) in Cameroon. The Yaoundé series belongs to the Southern domain of the PANEFB and it is composed of migmatites in which two types of granitic leucosomes (in situ leucosomes and injected leucosomes) have been distinguished. These rocks display characteristic of calc-alkaline (in situ leucosomes) and high-K calc-alkaline to shoshonitic series (injected leucosomes). All the rocks are peraluminous with in situ leucosomes conform to S-type and injected leucosomes conform to I- and S-type granitoids. Major and trace elements composition reveal that in situ leucosomes derived from the partial melting of the host metapelite whereas injected leucosomes derived from the melting of metagreywacke. These sources are similar to those of granitoids from central and northern domains of the PANEFB. Th-U-Pb dating by electron microprobe (EMP) and LA-ICP-MS U-Pb dating on zircon have been used to constraints the melting event and emplacement of leucosomes in Yaoundé series. Th- $\mathrm{U}-\mathrm{Pb}$ monazite dating, undertaken in two samples of leucosomes, gives two groups of monazite ages. The older group gives an age of $658 \mathrm{Ma}$ whereas the age of younger group is $592 \mathrm{Ma}$. U-Pb dating of zircons from the leucosomes reveals a Pan-African age ranging from 626 to $654 \mathrm{Ma}$ whereas zircons from metapelitic host rock reveal the overprinting of an early Pan-African event 911 - 1127 Ma on Palaeoproterozoic (2127 Ma) inheritance. These data clearly indicate that the host rocks of leucosomes of Yaoundé series have been firstly metamorphosed during Tonien-Stenien period (911 - 1127 Ma) and reveal the existence of extended unique melting event (592 and $658 \mathrm{Ma}$ ) in the Yaoundé series which is contemporaneous with the magmatism responsible for the emplacement of granitoids in the other domains of the PANEFB.
\end{abstract}

Keywords: Pan-African North-Equatorial Fold Belt; Yaoundé Series; EMP Monazite Dating; LA-ICP-MS U-Pb Dating; Leucosomes; Peraluminous; Melting Event; Magmatism

\section{Introduction}

Peraluminous magmatism is largely reported in the collisional belt. However, this magmatism is also observed, but in least proportion, in the passive margin setting where it is expressed by volcanic tuffs [1,2]. The study of metamorphic and igneous rocks provides important information on the magmatic processes which took place in the continental lithosphere, especially in the collisional belt. In this type of orogeny, there is a strong relation

\footnotetext{
${ }^{*}$ Corresponding author.
}

between metamorphism, deformation, melting and/or magmatism. The study of the granitic melt is of fundamental importance for the understanding of the main processes of genesis and evolution of the continental crust and notably of the palingenesis.

Till date, peraluminous magmatism in Cameroon is only reported in the northern and the central domains of the Pan-African North-Equatorial Fold Belt (PANEFB). The study of the leucosomes in the migmatites of Yaoundé in the southern domain of the PANEFB has revealed their granitic composition and their peralumi- 
nous affinity. The ubiquity of the magmatism in the PANEFB, which spreads more than $500 \mathrm{~km}$, from the northern domain to the southern domain, can be assigns either to the existence of a unique melting event along the belt, or to distinct melting episodes. Indeed, the uniqueness of metamorphic and tectonic phenomena throughout the PANEFB was demonstrated by many authors [3-5].

This paper presents the results of geochemical and geochronological studies of the leucosomes of the southern domain of the Pan-African North-Equatorial Fold Belt. These results, compared to those obtained on the granitoids of the northern and the central domains, allow us 1) to identify the magma sources all over the PanAfrican North-Equatorial Fold Belt and 2) to indicate their production periods (ages) and emplacement within the formations of the PANEFB in Cameroon.

\section{Regional Geological Setting}

The Yaoundé series belongs to the Southern domain of the Pan-African North-Equatorial fold belt and is situated in the northern edge of the Congo craton (Figure 1). It is composed of intensely deformed metasedimentary and meta-igneous rocks [6]. The metasedimentary rocks are made up of chlorite schist, garnet and/or kyanite bearing micaschist and garnet and kyanite bearing gneisses. The protoliths of these rocks are shale and greywacke deposited in an intracontinental rift context or thinned margin $[6,7]$. These metasediments are locally intruded by diorite and/or granodiorite and metamorphosed under HP$\mathrm{HT}$ conditions $\left(\mathrm{T}=750^{\circ} \mathrm{C}-800^{\circ} \mathrm{C}, \mathrm{P}=0.9-1.3 \mathrm{GPa} ;[6\right.$, 8]) at $620 \pm 10 \mathrm{Ma}(\mathrm{U}-\mathrm{Pb}$ age on zircon; [9]) or at 616 $\mathrm{Ma}$ (U-Pb age on zircon and Sm-Nd; [10]) and or between $613 \pm 33 \mathrm{Ma}$ and $586 \pm 15 \mathrm{Ma}$ (Th-U-Pb age on monazite; [11]).

The rocks of this unit have been affected by two major phases of deformation associated to the metamorphism [6, 12,13]: 1) the $D_{1}$ phase is marked by a compositional bedding $\left(\mathrm{So} / \mathrm{S}_{1}\right)$ parallel to the preferential orientation of the phyllosilicates and ended by the formation of the high

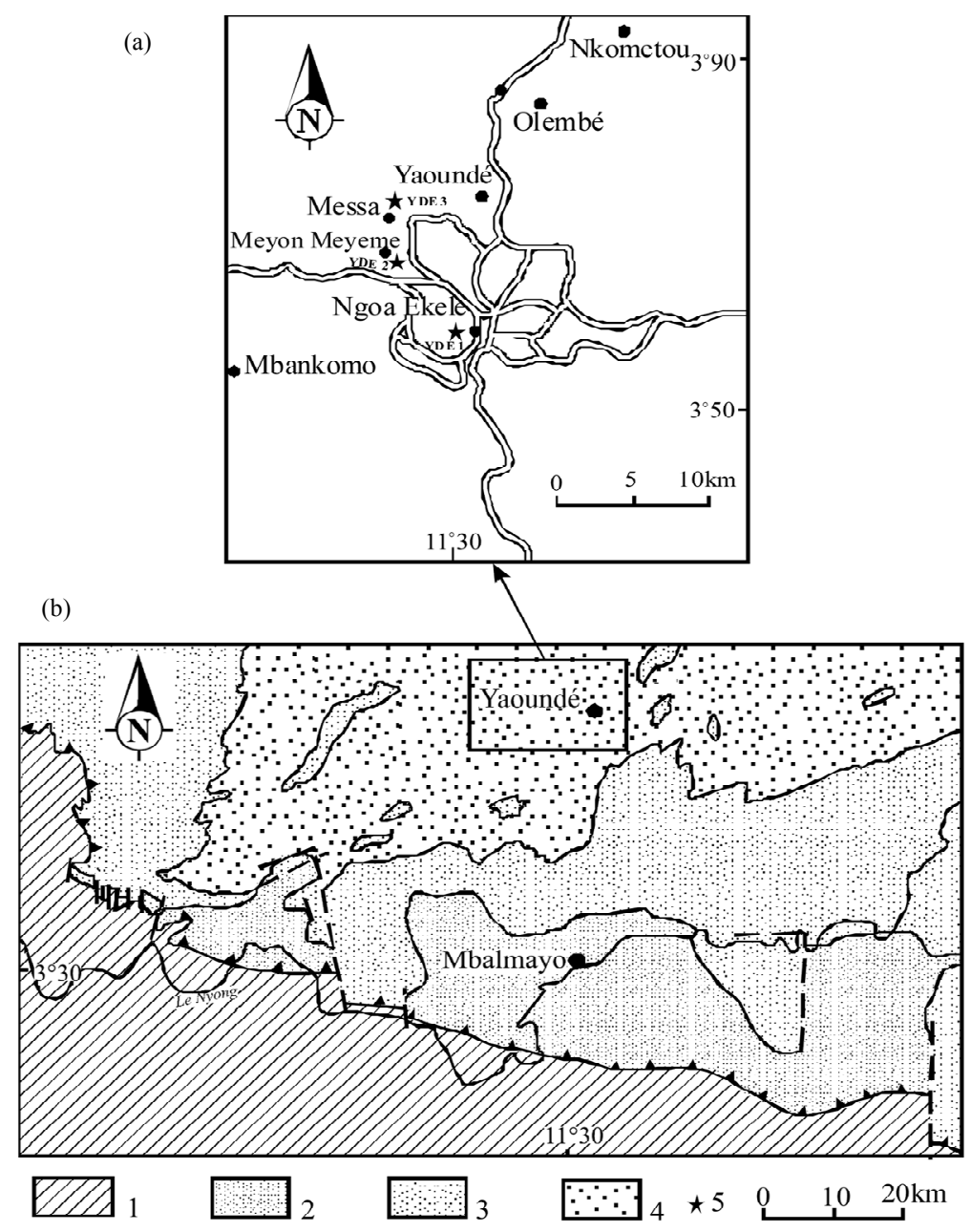

Figure 1. (a) Location map of the study area; (b) Geological map of Yaoundé group (adapted from [6]). 1: Congo Craton; 2: Mbalmayo series; 3 and 4: Yaoundé series (Garnet micaschist and migmatitic gneisses, respectively); 5: Sampling site. 
pressure granulite-facies assemblage and the beginning of partial melting; 2) the $\mathrm{D}_{2}$ event is a compressionnal phase marked by the intrusion of mafic rocks, the in situ partial melting, the injection of the quartzo-feldspathic melt along the $\mathrm{C}_{2}$ shear plane and by a southward thrusting of the rocks of this series onto the Archean Congo
Craton. The migmatisation develops mainly during this second phase.

In addition to the southern domain, the Pan-African North-Equatorial Fold Belt is made of two other geodynamic domains (the northern and the central domains, Figure 2):

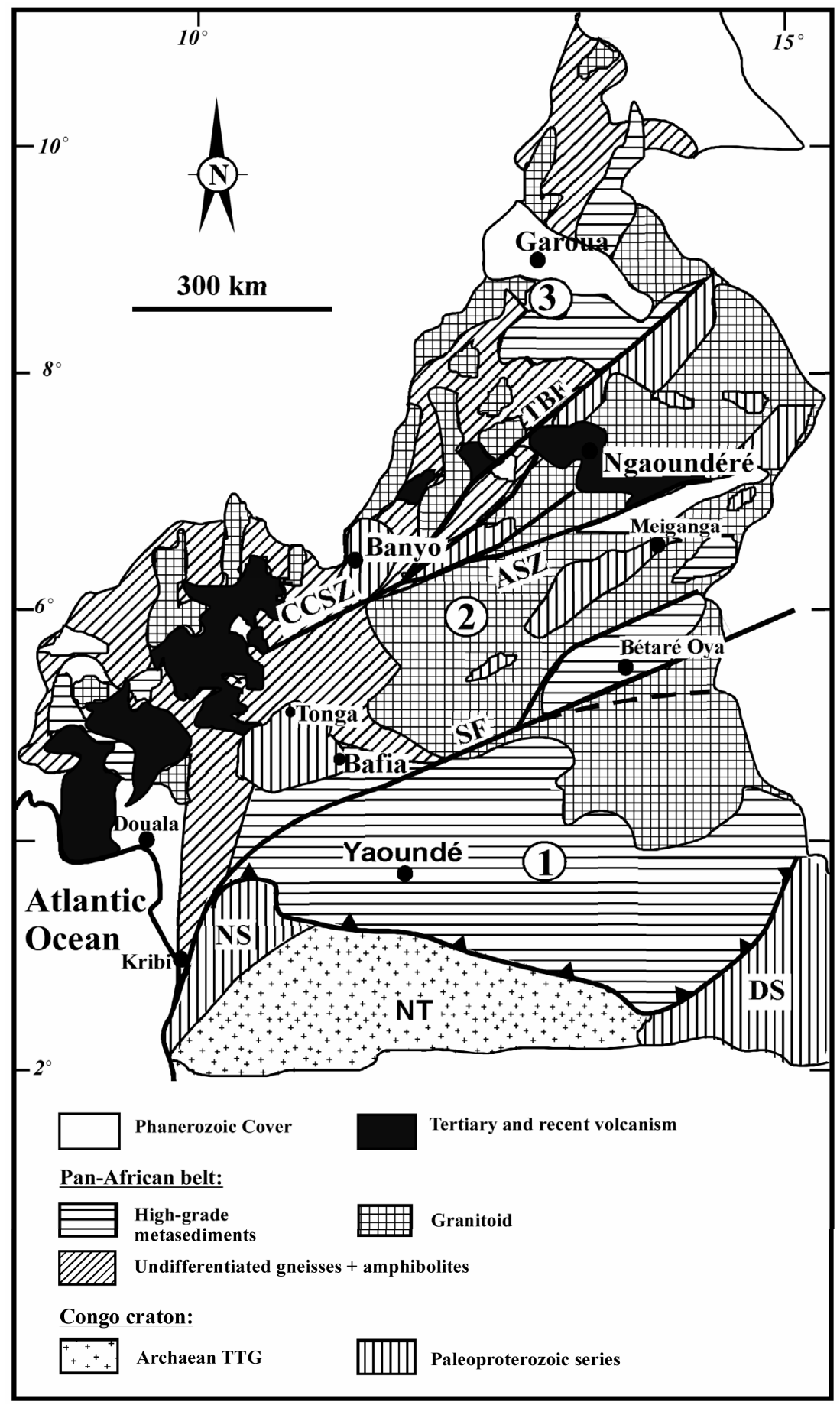

Figure 2. Geological map of Cameroon (adapted from [4]) showing the localization of the Yaoundé area and the three main lithotectonic domains of PANEFB: 1) Southern domain; 2) Central domain; 3) Northern domain. CCSZ: Central Cameroon Shear Zone); SF: Sanaga Fault; TBF: Tibati Banyo Fault; NT: Ntem Complex; DS: Dja Series; NS: Nyong Series. 
1) The northern domain, with polyphase and polycyclic evolution [14-18], consists of metavolcanite of tholeiitic and alkaline affinities associated with metasediments (Poli series) and widespread 630 - $660 \mathrm{Ma}$ calc-alkaline orthogneisses interpreted as major episode of accretion [17]. These orthogneisses contain granulitic relics of Palaeoproterozoic age (2100 Ma, [9]).

2) The central domain consists of an assembly of fragments of Paleoproterozoic continental crust recristallised under high-grade granulite facies $\left(850^{\circ} \mathrm{C}-900^{\circ} \mathrm{C}\right.$, $10-12 \mathrm{~Kb})$ at ca. $2100 \mathrm{Ma}[3,19,20]$ intruded by widespread Pan-African syntectonic granitoids. These granitoids have high-K calc-alkaline to shoshonitic affinities. They are either S-type peraluminous granite [4], or I-type metaluminous to weakly peraluminous granite [21-24] and are derived from the partial melting of the metapelite or metagreywacke sources. Their emplacement age ranges from $558 \mathrm{Ma}$ to $621 \mathrm{Ma}[19,21,24-26]$.

\section{Analytical Procedures}

\subsection{Whole Rock Geochemistry}

Samples were collected from fresh outcrops in quarries around Yaoundé. Leucosomes were separated from each other in a set of centimeter-thick slabs cut perpendicular to the foliation of the samples. Major elements, as well as $\mathrm{Rb}, \mathrm{Sr}, \mathrm{Zr}, \mathrm{Nb}$, and $\mathrm{Y}$, were determined by $\mathrm{X}$-ray fluorescence (XRF) spectrometry at the University of Nancy I using the procedure outlined by Govindaraju \& Montanari [27]; Th, $\mathrm{U}$ and rare earth elements (REE) were determined by inductively coupled plasma emission spectrometry (ICP-ES) and by absorption spectrometry at CRPG, Nancy [28]. Analytical uncertainties are estimated at $2 \%$ for major elements, and at $5 \%$ or $10 \%$ for trace element concentrations higher or lower than 20 ppm respectively. Precision for REE is 5\% when chondrite-normalized concentrations are $>10$ and $10 \%$ when there are lower. Samples are normalized to chondrite using the factors presented by Jahn et al. [29].

\subsection{EMP Method}

Analysis of $\mathrm{Th}, \mathrm{U}$ and $\mathrm{Pb}$ for calculation of monazite model ages, as well as for $\mathrm{Ca}, \mathrm{Si}$, LREE and $\mathrm{Y}$ for corrections and evaluation of the mineral chemistry were carried out on a JEOL JXA 8200 (Chair of Mineralogy, University of Erlangen-Nürnberg) at $20 \mathrm{kV}, 100 \mathrm{nA}$, and a beam size of $5 \mu \mathrm{m}$ [30]. M1 lines of $\mathrm{Th}$ and $\mathrm{Pb}$ and the M1 lines for $U$ of a PETH crystal were selected for analysis. Resulting errors $(1 \sigma)$ are typically $1.0 \%, 0.20 \%$ and $1.30 \%$ for $\mathrm{Pb}$, Th and $\mathrm{U}$, respectively, based on counting statistics. The lines $\mathrm{L} \alpha 1$ for $\mathrm{La}, \mathrm{Y}, \mathrm{Ce} ; \mathrm{L} \beta 1$ for $\mathrm{Pr}, \mathrm{Sm}, \mathrm{Nd}, \mathrm{Gd}$ and $\mathrm{K} \alpha 1$ for $\mathrm{P}, \mathrm{Si}$ and $\mathrm{Ca}$ were chosen. Orthophosphates of the Smithsonian Institution were used as standards for REE analysis [31,32]. Calibration of $\mathrm{PbO}$ was carried out on a vanadinite standard, while $\mathrm{U}$ was calibrated on an appropriate glass standard with 5 $\mathrm{wt} \% \mathrm{UO}_{2}$. The Madmon monazite [30], dated by SHRIMP at $489 \pm 9 \mathrm{Ma}$ and numerous $\mathrm{Pb}$-Pb-TIMS monazite evaporation data at $497 \pm 2 \mathrm{Ma}$, contains $\mathrm{ThO}_{2}$ at around $10 \mathrm{wt} \%$. The $\mathrm{ThO}_{2}$ in Madmon was previously determined by LA-ICPMS and by the microprobe at University of Salzburg [33] and was used for calibration of $\mathrm{ThO}_{2}$ as well as for the control of data. Interference of $\mathrm{YL} \gamma$ on the $\mathrm{PbM}$ line was corrected by linear extrapolation after measuring several $\mathrm{Pb}$-free yttrium glass standards as proposed by Montel et al. [34]. An interference of ThM $\gamma$ on UM was also corrected by using a Th-glass standard. Interference of a Gd-line on $\mathrm{UM} \beta$ needs correction when $\mathrm{Gd}_{2} \mathrm{O}_{3}$ in monazite is $>5 \mathrm{wt} \%$. These parameters matched the analytical problems discussed in [35] in the best way [30]. For each single analysis, a chemical age (CHIME) and a $2 \sigma$ error based on the $\mathrm{Pb}$ counting statistics was calculated. Other possible sources of error, as standardization, matrix effect correction, $\mathrm{YL} \gamma$-on- $\mathrm{PbM} \alpha$ correction and instrumental drift were not taken into account. Therefore the given error on the calculated ages should be considered as a minimum error.

\subsection{U-Pb LA-ICP-MS Method}

$\mathrm{U}-\mathrm{Pb}$ isotopic analyses were performed in the geochronology laboratory of the University of Brasilia and followed the analytical procedure described by Buhn et al. [36]. Zircon concentrates were extracted from ca. $10 \mathrm{~kg}$ rock samples using conventional gravimetric and magnetic techniques at the geochronology laboratory of the University of Brasilia. Mineral fractions were hand picked under a binocular microscope to obtain fractions of similar size shape and colour.

For in situ ICP-MS analyses, hand picked zircon grains were mounted in epoxy blocks and polished to obtain a smooth surface. Backscattered electron and cathodoluminescence images were obtained using a scanning electron microscope in order to investigate the internal structures of zircon crystals prior to analysis.

Before LA-ICP-MS analyses, mounts were cleaned with dilute (ca. $2 \% \mathrm{HNO}_{3}$. The samples were mounted in a specially adapted laser cell and loaded into a new Wave UP213 Nd: YAG laser $(\lambda=213)$, linked to a Thermo Finnigan Neptune Multi-collector ICPMS. Helium was used as the carrier gas and mixed with argon before entering the ICP. The laser was run at a frequency of $10 \mathrm{~Hz}$ and energy of $34 \%$. In order to avoid down-hole fractionation during ablation, we adopted for a raster scan of about $70 \mu \mathrm{m}$ in total diameter with a spot size of $30 \mu \mathrm{m}$.

Two international zircon standards were analysed throughout the U-Pb analyses. The zircon standard GJ-1 
[37] was used as the primary standard in a standardsample bracketing method, accounting for mass bias and drift correction.

The resulting correction factor for each sample analysis considers the relative position of each analysis within the sequence of 4 samples bracketed by two standard and two blank analyses each [38]. The Temora 2 standard [39] was run at the start and the end of each analytical session, yielding an accuracy around $2 \%$ and a precision in the range of $1 \%$. The errors of sample analyses were propagated by quadratic addition of the external uncertainty observed for the standards to the reproducibility and within run precision off each unknown analysis. The instrumental set-up and further details of the analytical method applied are given by Buhn et al. [36].

The masses 204, 206 and 207 are measured with ion counters, and ${ }^{238} \mathrm{U}$ was analyzed on a Faraday cup. The signal of ${ }^{202} \mathrm{Hg}$ was monitored on an ion counter for correction of the isobaric interference between ${ }^{204} \mathrm{Hg}$ and ${ }^{204} \mathrm{~Pb}$. The signals during ablation were taken in 40 cycles of $1 \mathrm{sec}$ each. For data evaluation, only coherent intervals of signal response were considered. Data reduction was performed with an Excel spreadsheet developed by one of the authors that considers blank values, zircon standards composition and errors propagation. The ${ }^{204} \mathrm{~Pb}$ signal intensity was calculated and corrected using a natural ${ }^{202} \mathrm{Hg} /{ }^{204} \mathrm{Hg}$ ratio of 4.346 . A common $\mathrm{Pb}$ correction was applied for zircons with ${ }^{206} \mathrm{~Pb} /{ }^{204} \mathrm{~Pb}$ lower than 1000 , applying a common lead composition following the Stacey and Kramers model [40]. Plotting of U-Pb data was performed by ISOPLOT v.3 [41] and errors for isotopic ratios are presented at the $2 \sigma$ level. Because of the statistical treatment applied in calculating Concordia ages, those are more precise than any individual $\mathrm{U} / \mathrm{Pb}$ or $\mathrm{Pb} / \mathrm{Pb}$ ages [42] and, in data herein presented, always correspond to less than the $2 \%$ accuracy obtained from the intercalibration of the standards. Consequently, the Isoplot calculated errors were modified in order to incorporate this uncertainty level and, hence, represent a more realistic age in terms of the analytical limitations of the method.

\section{Results}

\subsection{Petrography and Mineral Chemistry}

Two main types of leucosomes have been distinguished on the basis of petrographic and structural criteria:

1) Injected leucosomes

Injected leucosomes occur in two manners: i) along the $\mathrm{C}_{2}$ shear zone; ii) as cross-cutting dykes (Figure 3(a)). They are observed in both metapelitic gneisses and metabasites where they are sometimes associated with ultramafic dykes. Injected leucosomes are either:

i) fine-grained, composed of ribbons quartz $(25 \%$ $30 \%)$, large perthitic K-feldspar $\left(\mathrm{Or}_{95} \mathrm{Ab}_{5}-\mathrm{Or}_{89} \mathrm{Ab}_{11}\right)$ crystals, euhedral plagioclase (5\% - 10\%) crystals rarely zoned showing deformed twins (Figure 3(b)). Garnet $(<3 \%)$ occurred as euhedral crystals or as atoll including
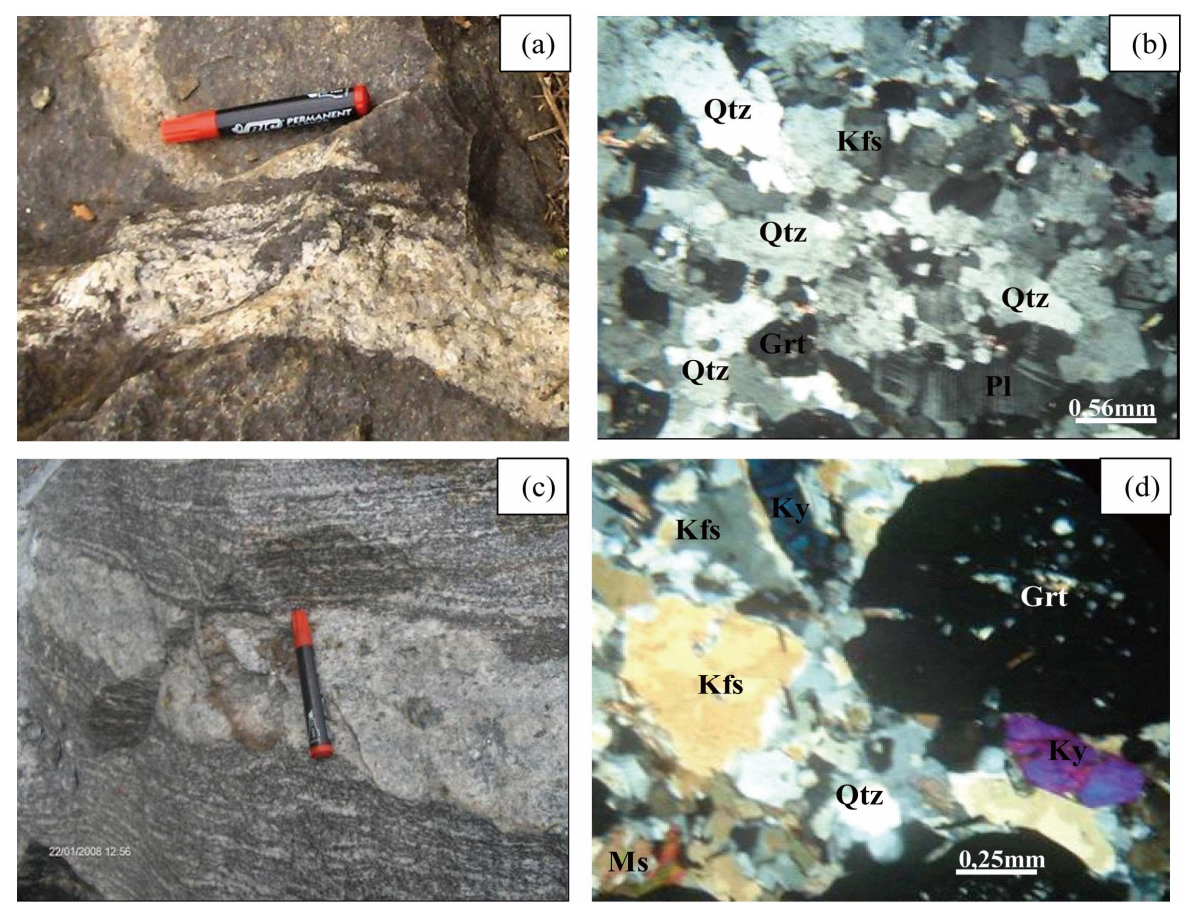

Figure 3. Field occurrences of injected leucosomes (a) and in situ leucosomes (c), and detail of microstructure of injected leucosomes (b) and in situ leucosomes (d). 
muscovite, rutile, plagioclase and quartz. The average mineral composition of garnet is presented in Table 1. Garnet forms solid solution (Figure 4) of almandine $\left(\mathrm{X}_{\mathrm{Fe}}\right.$ : $0.63-0.68)$ rich in pyrope $\left(\mathrm{X}_{\mathrm{Mg}}: 0.24-0.30\right)$ meanwhile kyanite $(<2 \%)$ is prismatic, crackled crystals associated with garnet. Accessory minerals include apatite, zircon, monazite and rutile;

ii) coarse-grained, mainly composed of ribbons or interstitial quartz $(25 \%-40 \%)$, plagioclase, K-feldspar and biotite. Plagioclase $\left(10 \%-45 \% ; \mathrm{An}_{17}-\mathrm{An}_{18}\right)$ occurs as euhedral antiperthitic crystals with deformed twins and sometimes as porphyroblasts with inclusions of quartz and biotite flakes. K-feldspar (10\% - 50\%) occurs as large crystals and is often perthitic $\left(\mathrm{Or}_{95} \mathrm{Ab}_{5}-\mathrm{Or}_{86} \mathrm{Ab}_{14}\right)$. Biotite $(<2 \%)$ is of magnesian composition $\left(\mathrm{X}_{\mathrm{Mg}}: 0.62-\right.$ 0.67 , Table 2; Figure 5) and occurs as flakes of various dimensions, most of which contain small inclusions of zircon and apatite. Accessories are monazite, zircon, apatite and often sillimanite, calcite, tourmaline and muscovite.

2) In situ leucosomes

In situ leucosomes are the most abundant in the Yaoundé series. They are observed in both metapelite and metabasite (Figure 3(c)), structured or not, medium to coarsed-grained, mainly composed of quartz, plagioclase, K-feldspar and garnet. Quartz (30\% - 35\%) forms elongated or interstitial crystals with undulatory extinction. Plagioclase $\left(\mathrm{An}_{21}-\mathrm{An}_{24} ; 20 \%-60 \%\right)$ are anhedral and antiperthitic $\left(\mathrm{Or}_{92} \mathrm{Ab}_{8}-\mathrm{Or}_{90} \mathrm{Ab}_{10}\right)$ crystal with polycrystalline almond shape. K-feldspar $(10 \%-20 \%)$ is

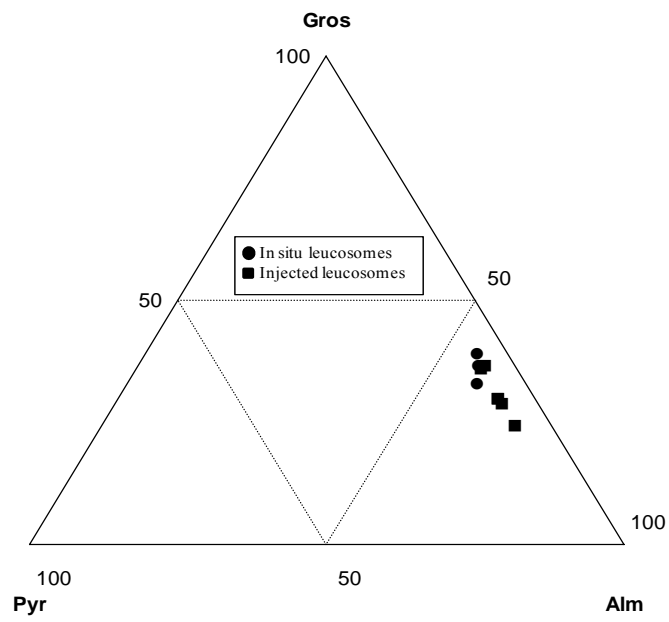

Figure 4. Triangular diagram showing the nature of garnet in Yaoundé leucosomes.

Table 1. Electron microprobe data of garnet from Yaoundé leucosomes.

\begin{tabular}{|c|c|c|c|c|c|c|c|c|c|}
\hline \multirow{2}{*}{$\frac{\text { Rocks }}{\mathrm{N}^{\circ}}$} & \multicolumn{3}{|c|}{ In situ leucosomes } & \multicolumn{6}{|c|}{ Injected leucosomes } \\
\hline & 3 & 16 & 19 & 6 & 7 & 8 & 15 & 16 & 17 \\
\hline $\mathrm{SiO}_{2}$ & 39.31 & 39.50 & 38.70 & 39.25 & 38.36 & 38.32 & 37.80 & 38.88 & 38.67 \\
\hline $\mathrm{Al}_{2} \mathrm{O}_{3}$ & 22.82 & 22.96 & 22.74 & 22.85 & 22.77 & 23.00 & 23.31 & 22.65 & 22.81 \\
\hline $\mathrm{FeO}$ & 27.31 & 26.93 & 25.46 & 28.27 & 30.06 & 28.54 & 28.81 & 26.16 & 27.03 \\
\hline $\mathrm{MnO}$ & 0.69 & 0.79 & 0.50 & 0.61 & 0.86 & 0.50 & 0.52 & 0.77 & 0.50 \\
\hline $\mathrm{MgO}$ & 8.58 & 9.70 & 10.19 & 7.50 & 5.98 & 7.44 & 7.70 & 9.23 & 9.46 \\
\hline $\mathrm{CaO}$ & 2.88 & 2.26 & 1.96 & 1.85 & 2.01 & 2.20 & 1.89 & 2.06 & 2.29 \\
\hline TOTAL & 101.58 & 101.14 & 99.55 & 100.33 & 100.04 & 100.00 & 100.03 & 99.75 & 100.76 \\
\hline \multicolumn{10}{|c|}{ Structural formula on the basis of 24 oxygens } \\
\hline $\mathrm{Si}$ & 5.956 & 5.936 & 5.924 & 6.031 & 5.975 & 5.933 & 5.860 & 5.966 & 5.902 \\
\hline $\mathrm{Al}$ & 4.075 & 4.067 & 4.102 & 4.137 & 4.180 & 4.196 & 4.258 & 4.095 & 4.102 \\
\hline $\mathrm{Fe}$ & 3.462 & 3.384 & 3.259 & 3.631 & 3.924 & 3.694 & 3.733 & 3.357 & 3.450 \\
\hline $\mathrm{Mn}$ & 0.088 & 0.100 & 0.065 & 0.079 & 0.114 & 0.066 & 0.068 & 0.100 & 0.065 \\
\hline $\mathrm{Mg}$ & 1.939 & 2.172 & 2.325 & 1.717 & 1.391 & 1.716 & 1.778 & 2.110 & 2.151 \\
\hline $\mathrm{Ca}$ & 0.467 & 0.364 & 0.322 & 0.304 & 0.336 & 0.365 & 0.314 & 0.338 & 0.374 \\
\hline $\operatorname{Alm}(\mathrm{Fe})$ & 0.58 & 0.56 & 0.55 & 0.64 & 0.63 & 0.68 & 0.63 & 0.57 & 0.57 \\
\hline Pyr (Mg) & 0.33 & 0.36 & 0.39 & 0.29 & 0.30 & 0.24 & 0.30 & 0.36 & 0.36 \\
\hline $\mathrm{Sp}(\mathrm{Mn})$ & 0.01 & 0.02 & 0.01 & 0.01 & 0.01 & 0.02 & 0.01 & 0.02 & 0.01 \\
\hline
\end{tabular}


Table 2. Electron microprobe data of biotite from Yaoundé leucosomes.

\begin{tabular}{|c|c|c|c|c|c|c|c|c|c|}
\hline \multirow{2}{*}{$\begin{array}{c}\text { Rocks } \\
\mathrm{N}^{\circ}\end{array}$} & \multicolumn{6}{|c|}{ In situ leucosomes } & \multicolumn{3}{|c|}{ Injected leucosomes } \\
\hline & 44 & 45 & 47 & 48 & 49 & 50 & 35 & 36 & 37 \\
\hline $\mathrm{SiO}_{2}$ & 38.03 & 37.70 & 37.65 & 38.16 & 38.04 & 37.71 & 37.61 & 38.20 & 37.22 \\
\hline $\mathrm{Al}_{2} \mathrm{O}_{3}$ & 18.28 & 18.04 & 18.48 & 18.24 & 17.69 & 18.48 & 17.38 & 17.30 & 17.64 \\
\hline $\mathrm{FeO}$ & 12.39 & 12.12 & 12.00 & 11.49 & 12.17 & 11.96 & 11.59 & 1.61 & 11.45 \\
\hline $\mathrm{MgO}$ & 13.19 & 13.22 & 12.71 & 12.92 & 13.16 & 13.13 & 13.59 & 13.59 & 13.42 \\
\hline $\mathrm{K}_{2} \mathrm{O}$ & 9.82 & 10.00 & 9.85 & 10.05 & 9.99 & 9.60 & 9.77 & 9.80 & 9.82 \\
\hline $\mathrm{TiO}_{2}$ & 3.89 & 3.94 & 3.97 & 3.80 & 3.92 & 4.04 & 4.55 & 4.65 & 3.89 \\
\hline TOTAL & 95.70 & 95.02 & 94.66 & 94.66 & 94.97 & 94.92 & 94.92 & 95.15 & 93.44 \\
\hline \multicolumn{10}{|c|}{ Structural formula on the basis of 22 oxygens } \\
\hline $\mathrm{Si}$ & 5.549 & 5.545 & 5.538 & 5.608 & 5.594 & 5.533 & 5.536 & 5.598 & 5.513 \\
\hline $\mathrm{Al}^{\mathrm{IV}}$ & 2.451 & 2.455 & 2.462 & 2.392 & 2.406 & 2.467 & 2.464 & 2.402 & 2.487 \\
\hline $\mathrm{Al}^{\mathrm{VI}}$ & 0.694 & 0.672 & 0.741 & 0.768 & 0.661 & 0.728 & 0.551 & 0.586 & 0.591 \\
\hline $\mathrm{Fe}$ & 1.512 & 1.490 & 1.477 & 1.412 & 1.496 & 1.468 & 1.427 & 1.422 & 1.419 \\
\hline $\mathrm{Mg}$ & 2.869 & 2.899 & 2.787 & 2.831 & 2.885 & 2.871 & 2.982 & 2.968 & 2.963 \\
\hline K & 1.828 & 1.876 & 1.848 & 1.885 & 1.874 & 1.796 & 1.881 & 1.827 & 1.851 \\
\hline $\mathrm{Ti}$ & 0.426 & 0.436 & 0.439 & 0.420 & 0.433 & 0.446 & 0.517 & 0.501 & 0.518 \\
\hline $\mathrm{X}_{\mathrm{Mg}}$ & 0.65 & 0.66 & 0.65 & 0.67 & 0.66 & 0.66 & 0.68 & 0.68 & 0.68 \\
\hline
\end{tabular}

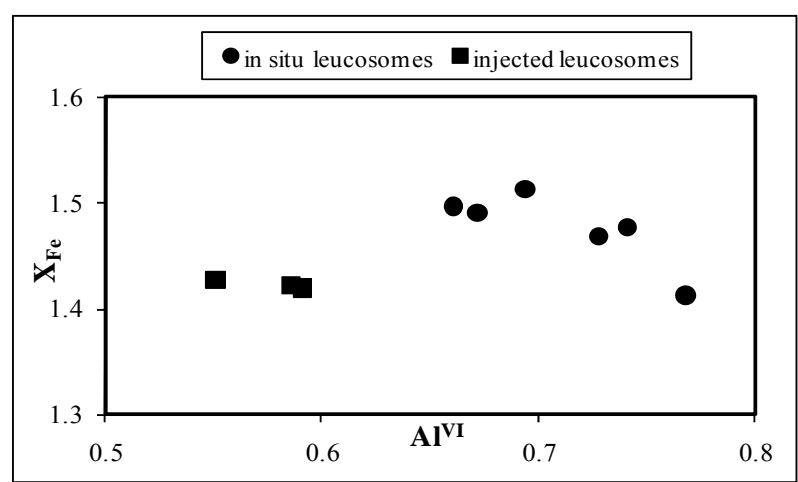

Figure 5. $\mathrm{X}_{\mathrm{Fe}} \mathrm{vs} \mathrm{Al}^{\mathrm{VI}}$ diagram showing the composition of biotite in Yaoundé leucosomes.

anhedral and perthitic $\left(\mathrm{Or}_{89} \mathrm{Ab}_{11}-\mathrm{Or}_{93} \mathrm{Ab}_{7}\right)$. The perthitic composition ranges from $\mathrm{An}_{18} \mathrm{Ab}_{82}$ to $\mathrm{An}_{20} \mathrm{Ab}_{80}$. Garnets $(<5 \%)$ appears as small euhedral crystals or zoned porphyroblasts (Figure 3(d)). The mineral composition of garnet is given in Table 1. They form a solid solution of almandine $\left(\mathrm{X}_{\mathrm{Fe}}: 0.55\right.$ to 0.58$)$ rich in pyrope $\left(\mathrm{X}_{\mathrm{Fe}}=0.33\right.$ to 0.39$)$ and poor in spessartine (Figure 4). Biotite $(\leq 3 \%)$ has magnesian composition $\left(\mathrm{X}_{\mathrm{Mg}}=0.65-0.67\right.$, Table 2) and appears as frayed flakes. Kyanite $(<2 \%)$ is corroded twinned euhedral crystals $(1-3 \mathrm{~mm})$. They are often oriented or lodged between plagioclase, K-feldspar, gar- net and quartz crystals (Figure 3(d)). Muscovite, monazite, zircon, rutile, apatite and oxides represent the accessory phase.

In the $\mathrm{X}_{\mathrm{Fe}}$ Vs Al ${ }^{\mathrm{VI}}$ biotite diagram (Figure 5), there is a significant difference between in situ leucosomes and injected leucosomes. In situ leucosomes are enriched in both aluminium and iron, whereas injected leucosomes are depleted with respect to the same elements.

\subsection{Geochemistry}

\section{1) Major elements}

We use the $\mathrm{Na}_{2} \mathrm{O}+\mathrm{K}_{2} \mathrm{O}$ vs $\mathrm{SiO}_{2}$ of Middlemost [43] for chemical classification of the different types of lecosomes. In situ leucosomes plot in granite while injected leucosomes plot in granite and quartz monzonite fields (Figure 6). The rocks are silica rich (with a $\mathrm{SiO}_{2}$ content ranging from 64.66 to $80.35 \mathrm{wt} \%$, Table 1) and show a variable content in total alkaline content $(3.53 \leq$ $\mathrm{Na}_{2} \mathrm{O}+\mathrm{K}_{2} \mathrm{O} \leq 4.84 \%$ for in situ leucosomes; $6.15 \leq$ $\mathrm{Na}_{2} \mathrm{O}+\mathrm{K}_{2} \mathrm{O} \leq 9.21 \%$ for injected leucosomes). This high alkaline content is also expressed by the $\mathrm{K}_{2} \mathrm{O} / \mathrm{Na}_{2} \mathrm{O}$ ratios range from 0.49 to 0.59 in in situ leucosomes and from 0.51 to 3.72 in injected leucosomes. In the $\mathrm{K}_{2} \mathrm{O}$ vs $\mathrm{SiO}_{2}$ diagram, the in situ leucosomes plot in the calc-alkaline domain while the injected leucosomes show high K-calcalkaline 


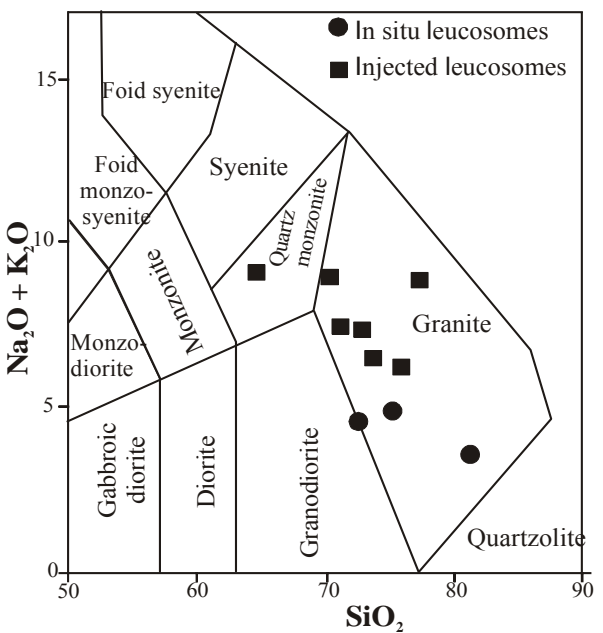

Figure 6. Classification diagram of plutonic rocks [43] showing the localization of the studied leucosomes in the granite field.

to shoshonitic affinities (Figure 7). In major elements variation diagrams vs $\mathrm{SiO}_{2}$ (Figure 8), the two rock types form well defined clusters, and taken together define more or less well-defined trends. In situ leucosomes show decreasing concentration of $\mathrm{K}_{2} \mathrm{O}, \mathrm{Al}_{2} \mathrm{O}_{3}, \mathrm{MgO}$, $\mathrm{TiO}_{2}$ and $\mathrm{CaO}$ with an increase in $\mathrm{SiO}_{2}$, while injected leucosomes show decreasing concentration of $\mathrm{Al}_{2} \mathrm{O}_{3}$, $\mathrm{TiO}_{2}, \mathrm{Fe}_{2} \mathrm{O}_{3}$ and $\mathrm{MgO}$ with an increase in $\mathrm{SiO}_{2}$. In the alumina index molar diagram $\left(\mathrm{Al}_{2} \mathrm{O}_{3} /\left(\mathrm{CaO}+\mathrm{Na}_{2} \mathrm{O}+\right.\right.$ $\left.\mathrm{K}_{2} \mathrm{O}\right)$ vs $\left.\mathrm{Al}_{2} \mathrm{O}_{3} /\left(\mathrm{Na}_{2} \mathrm{O}+\mathrm{K}_{2} \mathrm{O}\right)\right)$, all the rocks plot in peraluminous field with in situ leucosomes conform to S-type and injected leucosomes conform to S-type and I-type granitoids (Figure 9).

\section{2) Trace elements}

Trace elements concentrations of the different leucosomes are listed in Table 3. Selected elements are plotted against $\mathrm{SiO}_{2}$ in Figure 10. In in situ leucosomes, $\mathrm{Rb}$ and $\mathrm{Zr}$ concentrations decrease with increasing of $\mathrm{SiO}_{2}$ while $\mathrm{Y}, \mathrm{Sr}$ are scatter with increasing of $\mathrm{SiO}_{2}$. In injected leucosomes $\mathrm{Zr}, \mathrm{Sr}, \mathrm{Y}$ contents decrease when $\mathrm{SiO}_{2}$ contents increase (Figure 10). The $\mathrm{K} / \mathrm{Rb}$ ratios (261 361 for in situ leucosomes; average at 315 and $351-737$ for injected leucosomes; average at 480) are similar to those observed in the continental calc-alkaline igneous series $[44,45]$. Chondrite-normalized REE (the normalizing values are from Jahn et al. [29]) patterns show that the two types of leucosomes are much fractionated. In situ leucosomes have a strong LREE (Light Rare Earth Element) enrichment $\left(\mathrm{Ce}_{\mathrm{N}} / \mathrm{Sm}_{\mathrm{N}}=1.5\right.$ - 2.03) compared to HREE $\left(\mathrm{GD}_{\mathrm{N}} / \mathrm{Yb}_{\mathrm{N}}=1.20-1.54\right)$ with more pronounced positive $\mathrm{Eu}$ anomalies $\left(\mathrm{Eu} / \mathrm{Eu}^{*}=1.29\right.$ - 1.36) for some and weakly negative $\mathrm{Eu}$ anomalies $\left(\mathrm{Eu} / \mathrm{Eu}^{*}=0.93\right)$ for the others (Figure 11(A)). Injected leucosomes are also characterised by a strong HREE (heavy rare earth element) depletion $\left(\mathrm{Gd}_{\mathrm{N}} / \mathrm{Yb}_{\mathrm{N}}=1.60-16.20\right)$ and LREE

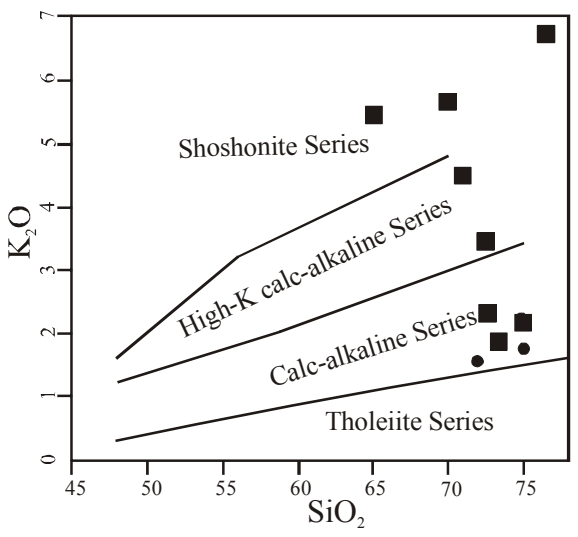

Figure 7. Diagram $\mathrm{K}_{2} \mathrm{O}$ vs $\mathrm{SiO}_{2}$ showing calc-alkaline, high-K to shoshonitic affinity of the Yaoundé leucosomes. Symbols as in Figure 6.

enrichment $\left(\mathrm{Ce}_{\mathrm{N}} / \mathrm{Sm}_{\mathrm{N}}=2.19\right.$ - 4.70; Figure 11(B)). The REE patterns lead to the distinction of two groups of injected leucosomes: 1) a first group (Figure 11(Ba)) characterized by strong Eu positive anomalies $\left(\mathrm{Eu} / \mathrm{Eu}^{*}=\right.$ $2.01-8.84$ ) and, 2) a second group (Figure 11(Bb)) with negative to null $\mathrm{Eu}$ anomalies $\left(\mathrm{Eu} / \mathrm{Eu}^{*}=0.63-1.22\right)$ and a strong enrichment in LREE $\left(\mathrm{Ce}_{\mathrm{N}} / \mathrm{Sm}_{\mathrm{N}}=2.19-4.70\right)$. These geochemistry behaviours are in accordance with subdivisions done in petrography.

\subsection{Geochronology}

\subsubsection{U-Th-Pb Age on Monazite}

Two samples of leucosomes (OL3A \& OL3B) were selected for $\mathrm{U}-\mathrm{Th}-\mathrm{Pb}$ monazite ages. These samples were chosen because they are more enriched in monazite crystals than other samples. The analyzed monazite crystals are of two main types: 1) globular or ovoid crystals, often crackled with no optical zoning (Figures 12(a) and (b)); 2) prismatic crystals, also with no optical zoning, but spotted by opaque granules which form inclusions in biotite flakes (Figures 12(b) and (c)). No systematic core-to-rim optical age zonation of were observed. This observation implies that monazite crystallize from melting liquid. This allows the calculation of ages composed of several single analyses by regression through zero [34] and of weighted means [41]. Chemical Th-U-Pb ages (Tables 4 and 5) have been gotten by Electron microprobe analysis (EMP). Two groups of ages, corresponding probably to the two events of monazite crystallisation, are recognised in the diagrams of mineral chemistry of monazite element vs Th-U-Pb chemical ages (Figures 13 and 14). The first event (younger) occurs at around 600 $\mathrm{Ma}$ and the second (older) at around $660 \mathrm{Ma}$. The analysed monazite age data are compared in the $\mathrm{PbO}$ vs $\mathrm{ThO}_{2} *$ diagram (Figure 15(a)) of Suzuki et al. [46]. On this diagram, the two generations of monazite previously described are clearly individualized. The average age of 
Table 3. Representative major (wt\%) and traces (ppm) elements analyses of the Yaoundé leucosomes.

\begin{tabular}{|c|c|c|c|c|c|c|c|c|c|c|c|c|c|c|}
\hline \multirow{3}{*}{ Samples } & \multicolumn{6}{|c|}{ In situ leucosomes } & \multicolumn{8}{|c|}{ Injected leucosomes } \\
\hline & \multirow[b]{2}{*}{ OL8b } & \multirow[b]{2}{*}{$16 \mathrm{~b}$} & \multirow[b]{2}{*}{ MB13b } & \multirow[b]{2}{*}{ MM86L } & \multirow[b]{2}{*}{ A16L } & \multirow[b]{2}{*}{ OL8L } & \multicolumn{3}{|c|}{ Fine grained } & \multicolumn{5}{|c|}{ Coarse grained } \\
\hline & & & & & & & MM14 & MB2a & MM20b & OL14 & MM2 & MM10 & MS20b & OL11 \\
\hline $\mathrm{SiO}_{2}$ & 72.03 & 74.66 & 80.35 & 72.73 & 74.7 & 72.03 & 64.66 & 69.57 & 72.1 & 70.79 & 72.77 & 73.01 & 75.54 & 77.22 \\
\hline $\mathrm{Al}_{2} \mathrm{O}_{3}$ & 13.07 & 11.97 & 8.62 & 15.06 & 12 & 13.07 & 18.24 & 16.47 & 15.63 & 15.38 & 16.18 & 15.98 & 14.78 & 12.08 \\
\hline $\mathrm{Fe}_{2} \mathrm{O}_{3}$ & 4.74 & 3.48 & 3.7 & 2.4 & 2.48 & 4.74 & 2.16 & 0.83 & 1.36 & 2.45 & 0.62 & 0.8 & 0.48 & 0.51 \\
\hline $\mathrm{MnO}$ & 0.06 & 0.06 & 0.05 & 0.06 & 0.06 & 0.06 & 0.05 & 0.01 & 0.01 & 0.04 & 0.02 & 0.03 & 0.01 & 0.02 \\
\hline $\mathrm{MgO}$ & 2.17 & 1.73 & 1.04 & 0.7 & 1.73 & 2.17 & 0.78 & 0.43 & 0.52 & 0.98 & - & 0.03 & 0.27 & 0.02 \\
\hline $\mathrm{CaO}$ & 1.91 & 2 & 1.24 & 2.1 & 2 & 1.91 & 3.04 & 2.25 & 1.95 & 1.96 & 2.68 & 2.57 & 2.14 & 0.39 \\
\hline $\mathrm{Na}_{2} \mathrm{O}$ & 2.86 & 3.1 & 2.01 & 3.56 & 3.1 & 2.86 & 3.93 & 3.49 & 3.88 & 3.5 & 4.28 & 3.84 & 3.79 & 1.87 \\
\hline $\mathrm{K}_{2} \mathrm{O}$ & 1.7 & 1.74 & 1.52 & 1.73 & 1.74 & 1.7 & 5.18 & 5.41 & 3.37 & 3.92 & 2.17 & 2.55 & 2.36 & 6.97 \\
\hline $\mathrm{TiO}_{2}$ & 0.7 & 0.52 & 0.41 & 0.3 & 0.52 & 0.7 & 0.35 & 0.27 & 0.21 & 0.31 & 0.08 & 0.12 & 0.11 & 0.7 \\
\hline $\mathrm{P}_{2} \mathrm{O}_{5}$ & - & - & - & 0.06 & - & - & - & - & 0.02 & - & - & - & - & - \\
\hline LOI & 0.61 & 0.51 & 0.56 & 1.16 & 0.51 & 0.61 & 0.7 & 0.98 & 0.51 & 0.38 & 0.47 & 0.54 & 0.22 & 0.43 \\
\hline $\mathrm{Rb}$ & 54 & 40 & 39 & 33 & 40 & 54 & 107 & 123 & 38 & 93 & 29 & 36 & 46 & 165 \\
\hline $\mathrm{Sr}$ & 193 & 211 & 121 & 379 & 211 & 193 & 660 & 391 & 469 & 315 & 398 & 380 & 386 & 286 \\
\hline $\mathrm{Zr}$ & 185 & 135 & 83 & 75 & 135 & 135 & 164 & 99 & 97 & 80 & 41 & 91 & 40 & 18 \\
\hline $\mathrm{Nb}$ & 4 & 4 & 6 & & 4 & 4 & - & - & - & 3 & - & - & - & 2 \\
\hline $\mathrm{Y}$ & 25 & 22 & 24 & 10 & 22 & 22 & 15 & 11 & 18 & 16 & 10 & 11 & 10 & 9 \\
\hline $\mathrm{La}$ & 12.22 & 15.85 & 21 & 21.03 & 15.9 & 12.22 & 67.38 & 40.68 & 41.12 & 20.6 & 6.34 & 7.12 & 4.09 & 9.43 \\
\hline $\mathrm{Ce}$ & 24.53 & 31.91 & 44.27 & 41.91 & 31.9 & 24.53 & 142.71 & 79.36 & 79.58 & 40.59 & 10.48 & 12.79 & 6.51 & 14.96 \\
\hline $\mathrm{Nd}$ & 13.91 & 14.17 & 21.16 & 15.46 & 14.2 & 13.91 & 73.07 & 34.15 & 36.41 & 20.58 & 3.27 & 4.05 & 1.87 & 6.7 \\
\hline $\mathrm{Sm}$ & 3.75 & 3.39 & 4.57 & 3.18 & 3.39 & 3.75 & 15.38 & 6.17 & 7.31 & 4.31 & 0.64 & 0.71 & 0.33 & 1.31 \\
\hline $\mathrm{Eu}$ & 1.55 & 1.47 & 1.26 & 2.36 & 1.47 & 1.55 & 2.83 & 2.14 & 1.37 & 2.33 & 1.48 & 1.64 & 0.79 & 2.26 \\
\hline $\mathrm{Gd}$ & 3.54 & 3.17 & 3.59 & 2.64 & 3.17 & 3.54 & 11.49 & 4.48 & 6.35 & 2.97 & 0.53 & 0.77 & 0.23 & 0.88 \\
\hline Dy & 3.34 & 2.85 & 3.29 & 2.03 & 2.85 & 3.34 & 3.36 & 1.55 & 6.02 & 2.09 & 0.39 & 0.5 & 0.1 & 0.41 \\
\hline $\mathrm{Er}$ & 1.98 & 1.57 & 1.96 & 1.24 & 1.57 & 1.98 & 0.99 & 0.49 & 0.37 & 1.15 & 0.2 & 0.38 & 0.05 & 0.23 \\
\hline $\mathrm{Yb}$ & 2.17 & 1.65 & 2.41 & 1.25 & 1.65 & 2.17 & 0.57 & 0.26 & 0.35 & 1.12 & 0.17 & 0.38 & 0.05 & 0.16 \\
\hline $\mathrm{Lu}$ & 0.3 & 0.32 & 0.38 & 0.2 & 0.32 & 0.3 & 0.13 & 0.05 & 0.12 & 0.17 & 0.06 & 0.05 & 0.01 & 0.06 \\
\hline $\mathrm{K} / \mathrm{Rb}$ & 261 & 361 & 324 & - & - & - & 402 & 365 & 737 & 351 & 621 & 588 & 426 & 351 \\
\hline $\mathrm{Rb} / \mathrm{Sr}$ & 0.28 & 0.19 & 0.32 & - & - & - & 0.16 & 0.31 & 0.08 & 0.3 & 0.07 & 0.09 & 0.12 & 0.58 \\
\hline $\mathrm{Ca} / \mathrm{Sr}$ & 70.7 & 67.68 & 73.17 & - & - & - & 32.89 & 41.09 & 29.4 & 44.43 & 48.08 & 48.29 & 39.58 & 9.74 \\
\hline$(\mathrm{Ce} / \mathrm{Sm}) \mathrm{N}$ & 1.5 & 2.2 & 2.3 & 3.11 & 2.2 & 1.5 & 2.19 & 3.03 & 2.57 & 2.22 & 3.85 & 4.25 & 4.7 & 2.7 \\
\hline$(\mathrm{Gd} / \mathrm{Yb}) \mathrm{N}$ & 1.3 & 1.54 & 1.2 & 1.7 & 1.54 & 1.3 & 16.2 & 13.84 & 14.6 & 2.13 & 2.5 & 1.6 & 3.7 & 4.4 \\
\hline$(\mathrm{Ce} / \mathrm{Yb}) \mathrm{N}$ & 2.89 & 4.95 & 4.2 & 8.57 & 4.95 & 2.89 & 64.06 & 78.1 & 58.3 & 9.28 & 15.72 & 8.59 & 33.4 & 23.9 \\
\hline $\mathrm{Eu} / \mathrm{Eu}^{*}$ & 1.29 & 1.36 & 0.93 & 2.44 & 1.36 & 1.29 & 0.63 & 1.22 & 0.64 & 2.01 & 7.8 & 6.65 & 8.84 & 6.12 \\
\hline
\end{tabular}



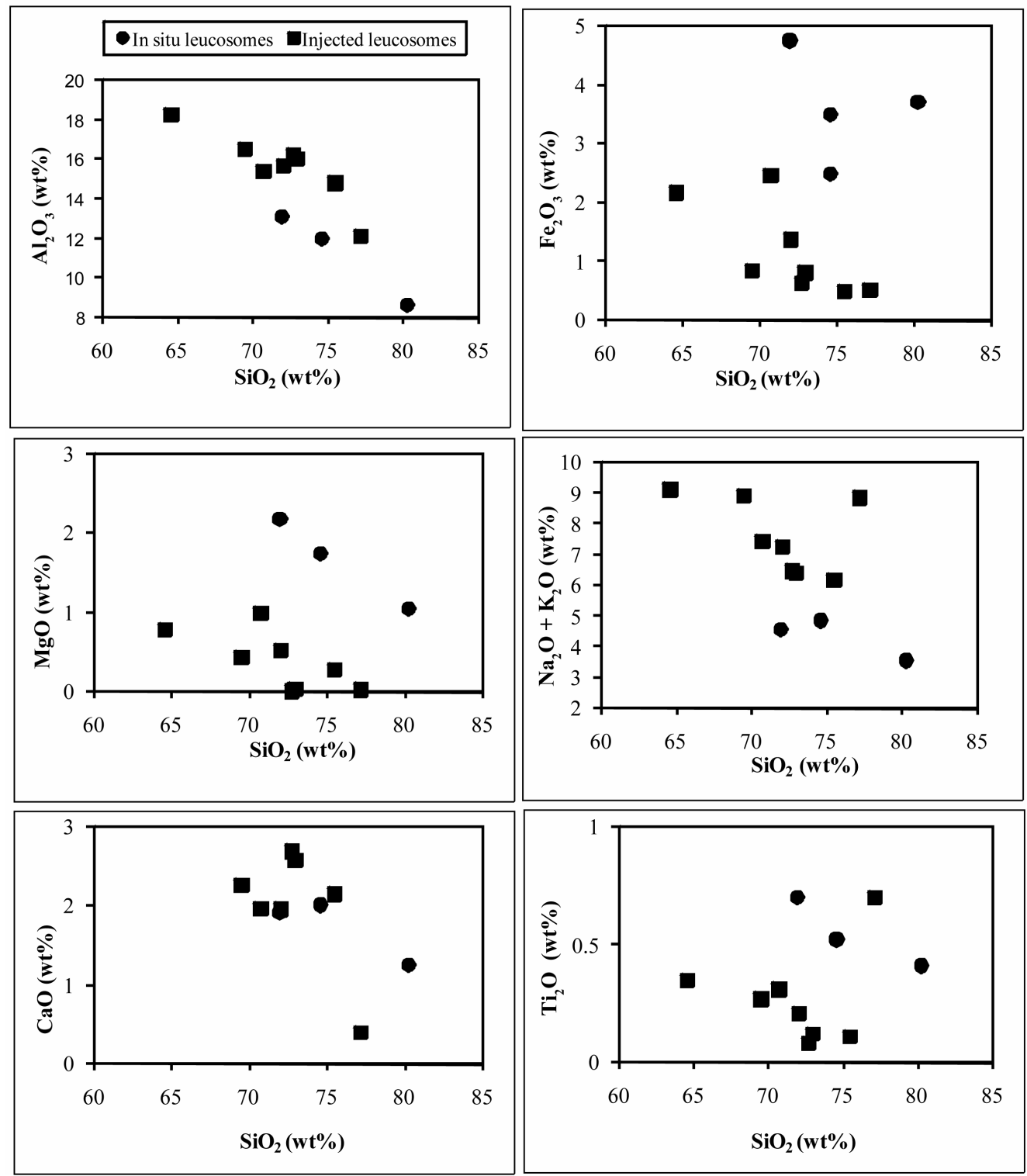

Figure 8. Harker diagrams of selected major elements. Symbols as in Figure 6.

the younger generation gives $592 \pm 10 \mathrm{Ma}$ while it gives $658 \pm 25 \mathrm{Ma}$ for the older one (Figure 15(b)). These two groups of ages seem to belong to the same thermal event because the petrography study reveals that all the monazite crystals are included in biotite flakes. Statistically, all these data can be considered as belonging to the same crystal population.

\subsubsection{LA-ICP-MS U-Pb Zircon Ages}

1) $\mathrm{U}-\mathrm{Pb}$ zircon ages of leucosomes

Fourteen grains of zircons from the leucosomes of metapelite were analyzed by the LA-ICP-MS method (Table 6). The Concordia diagrams (Figure 16) obtained reveal a concordant Pan-African age at $626 \pm 6.4 \mathrm{Ma}$ $(\mathrm{MSWD}=2.1$ ). The analyzed zircons crystals did not show any sign of a complex history. The obtained concordant ages correspond to the melting age during the Pan-African orogeny in Cameroon.

For the leucosomes occurring in metabasite, sixteen grains of zircons were analyzed by the same method. The obtained results (Table 7) define a Discordia (Figure 17) with an average Pan-African age at $654 \pm 6.7 \mathrm{Ma}$ $(\mathrm{MSWD}=1.3)$.

\section{2) U-Pb zircon age of metapelitic (basement)}

Two types of zircon crystals (zoned and no zoned) were identified in metasediment. Zoned zircon crystals are observed in the leucosomes from the metasediment whereas no zoned zircon crystals were selected from paleosome. The analytical results of no zoned zircons are listed on Table 8. The ages obtained define a Discordia 
Table 4. Electron microprobe analyses of monazite from Yaoundé leucosomes (sample OL3A). Monazite ages from single analyses are given with minimal error (see text).

\begin{tabular}{|c|c|c|c|c|c|c|c|c|c|c|c|c|c|c|c|c|c|c|}
\hline \multirow{2}{*}{$\begin{array}{c}\text { Sample } \\
\text { No }\end{array}$} & \multicolumn{18}{|c|}{ OL3A } \\
\hline & $\mathrm{SiO}_{2}$ & $\mathrm{Al}_{2} \mathrm{O}_{3}$ & $\mathbf{P}_{2} \mathbf{O}_{5}$ & $\mathrm{CaO}$ & $\mathbf{L a}_{2} \mathbf{O}_{3}$ & $\mathrm{Ce}_{2} \mathrm{O}_{3}$ & $\mathrm{Pr}_{2} \mathrm{O}_{3}$ & $\mathrm{Sm}_{2} \mathbf{O}_{3}$ & $\mathbf{N d}_{2} \mathbf{O}_{3}$ & $\mathbf{E u}_{2} \mathbf{O}_{3}$ & $\mathbf{G d}_{2} \mathbf{O}_{3}$ & $\mathrm{ThO}_{2}$ & $\mathbf{U O}_{2}$ & PbO & SrO & $\mathbf{Y}_{2} \mathbf{O}_{3}$ & Total & Age \\
\hline Madmon & 2.33 & 0.00 & 24.79 & 0.16 & 7.10 & 24.15 & 3.72 & 5.15 & 16.17 & 0.00 & 2.58 & 13.82 & 0.54 & 0.33 & 0.00 & 1.41 & 102.25 & 489 \\
\hline 7 & 0.25 & 0.03 & 30.65 & 1.05 & 14.12 & 28.94 & 3.00 & 1.88 & 12.48 & 0.82 & 1.18 & 4.25 & 0.47 & 0.15 & 0.13 & 0.77 & 100.17 & 577 \\
\hline 36 & 0.25 & 0.01 & 30.16 & 1.31 & 14.29 & 28.80 & 2.91 & 2.00 & 12.01 & 0.64 & 1.08 & 5.60 & 0.51 & 0.19 & 0.12 & 0.11 & 99.98 & 612 \\
\hline 37 & 0.23 & 0.00 & 30.08 & 1.30 & 14.39 & 28.80 & 2.83 & 1.96 & 11.74 & 0.64 & 1.06 & 5.51 & 0.50 & 0.19 & 0.13 & 0.11 & 99.47 & 631 \\
\hline 38 & 0.38 & 0.02 & 29.77 & 1.37 & 13.75 & 28.70 & 3.03 & 1.76 & 12.32 & 0.64 & 0.78 & 6.23 & 0.35 & 0.18 & 0.14 & 0.04 & 99.43 & 565 \\
\hline 39 & 0.40 & 0.02 & 29.85 & 1.34 & 13.78 & 28.56 & 3.04 & 1.81 & 12.62 & 0.62 & 0.75 & 6.19 & 0.34 & 0.18 & 0.14 & 0.01 & 99.65 & 588 \\
\hline 41 & 0.21 & 0.00 & 30.14 & 1.19 & 14.85 & 29.15 & 2.94 & 1.96 & 12.01 & 0.63 & 1.02 & 4.99 & 0.48 & 0.14 & 0.14 & 0.12 & 99.97 & 513 \\
\hline 65 & 0.80 & 0.15 & 29.24 & 1.35 & 14.44 & 28.48 & 3.01 & 1.81 & 11.91 & 0.73 & 0.94 & 5.19 & 0.69 & 0.20 & 0.14 & 0.14 & 99.20 & 615 \\
\hline 66 & 0.33 & 0.03 & 30.15 & 1.35 & 14.78 & 28.84 & 2.89 & 1.88 & 11.55 & 0.78 & 0.88 & 5.42 & 0.89 & 0.20 & 0.15 & 0.07 & 100.18 & 561 \\
\hline 68 & 0.37 & 0.02 & 30.03 & 1.13 & 13.87 & 27.98 & 2.69 & 2.10 & 11.30 & 0.89 & 1.49 & 4.88 & 0.76 & 0.18 & 0.14 & 0.94 & 98.74 & 561 \\
\hline 69 & 0.35 & 0.03 & 29.32 & 1.42 & 14.57 & 28.31 & 2.98 & 1.96 & 11.77 & 0.79 & 0.90 & 5.74 & 0.94 & 0.22 & 0.14 & 0.06 & 99.50 & 599 \\
\hline 70 & 0.37 & 0.03 & 30.19 & 1.30 & 14.49 & 28.78 & 2.94 & 1.92 & 11.81 & 0.73 & 0.99 & 5.33 & 0.67 & 0.19 & 0.14 & 0.06 & 99.92 & 586 \\
\hline 5 & 0.26 & 0.02 & 29.28 & 0.69 & 14.18 & 29.60 & 3.23 & 1.83 & 13.02 & 0.91 & 1.20 & 3.10 & 0.36 & 0.13 & 0.15 & 0.71 & 98.66 & 667 \\
\hline 6 & 0.21 & 0.01 & 30.57 & 0.80 & 13.86 & 28.91 & 3.00 & 1.96 & 12.19 & 0.97 & 1.35 & 3.10 & 0.41 & 0.13 & 0.14 & 1.34 & 98.93 & 651 \\
\hline 35 & 0.27 & 0.01 & 30.14 & 1.35 & 14.20 & 28.59 & 2.86 & 1.95 & 11.76 & 0.66 & 1.09 & 5.76 & 0.52 & 0.22 & 0.15 & 0.10 & 99.62 & 689 \\
\hline 42 & 0.35 & 0.01 & 30.07 & 1.38 & 13.79 & 28.77 & 3.00 & 1.86 & 12.51 & 0.61 & 0.75 & 6.19 & 0.37 & 0.20 & 0.14 & 0.05 & 100.04 & 650 \\
\hline 71 & 0.37 & 0.01 & 29.69 & 1.32 & 13.96 & 27.96 & 2.97 & 1.97 & 11.86 & 0.80 & 1.24 & 5.51 & 0.77 & 0.23 & 0.14 & 0.59 & 99.38 & 667 \\
\hline
\end{tabular}

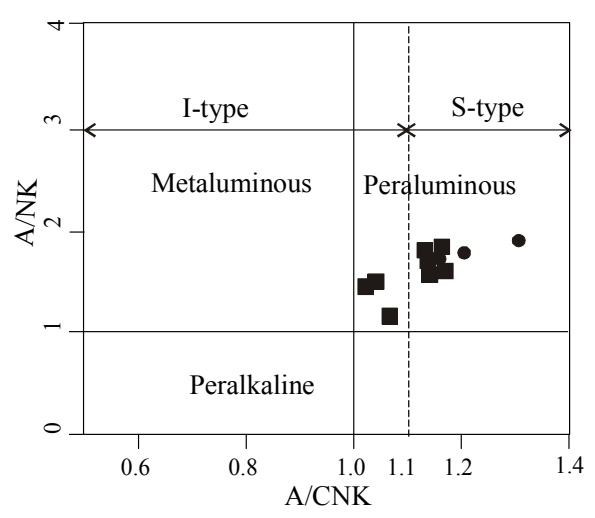

Figure 9. Molar A/NK vs A/CNK diagram showing the peraluminous character of Yaoundé leucosomes. Symbols as in Figure 6.

with upper intercept at $2127 \pm 150 \mathrm{Ma}$ and the lower intercept at $911 \pm 56 \mathrm{Ma}$ (Figures 18(a) and (b)). This means that the metapelitic rocks (in situ leucosomes rich) of the Yaoundé series underwent Paleoproterozoic history $(2127 \pm 150 \mathrm{Ma})$ before the overprinting of an early Pan-African event at around $911 \mathrm{Ma}$.

Zoned zircon crystals were also analyzed and their ra- diometric results are given in Table 9. The histogram (Figure 19(a)) of zoned zircon crystals shows two groups of ages. This is confirmed in the Discordia diagram (Figure 19(b)) where the ages are discordant and define two intercepts with upper intercept at $1122 \pm 110$ $\mathrm{Ma}$ and the lower one at $620 \pm 61 \mathrm{Ma}$. The $1122 \mathrm{Ma}$ age of the upper intercept confirms the existence within the Yaoundé series of a metamorphic event between 1122 $\mathrm{Ma}$ and $911 \mathrm{Ma}$ as revealed by radiometric data of no zoned zircon from metapelite. The lower intercept age $(620 \pm 61 \mathrm{Ma})$ is similar to the age previously obtained on no zoned zircons of metapelitic rock $(626 \pm 6 \mathrm{Ma}$; Figure 16) and probably corresponds to the melting age. The Tonien-Stenien event $(911-1122 \mathrm{Ma})$ is new in the Yaoundé series and in the Pan-African North-Equatorial Fold Belt in general. This period can be interpreted as the beginning of metamorphism in the Yaoundé series.

\section{Discussion}

\subsection{Origin and Petrogenesis of Leucosomes in the Yaoundé Series}

Peraluminous magmatism is commonly associated to the 

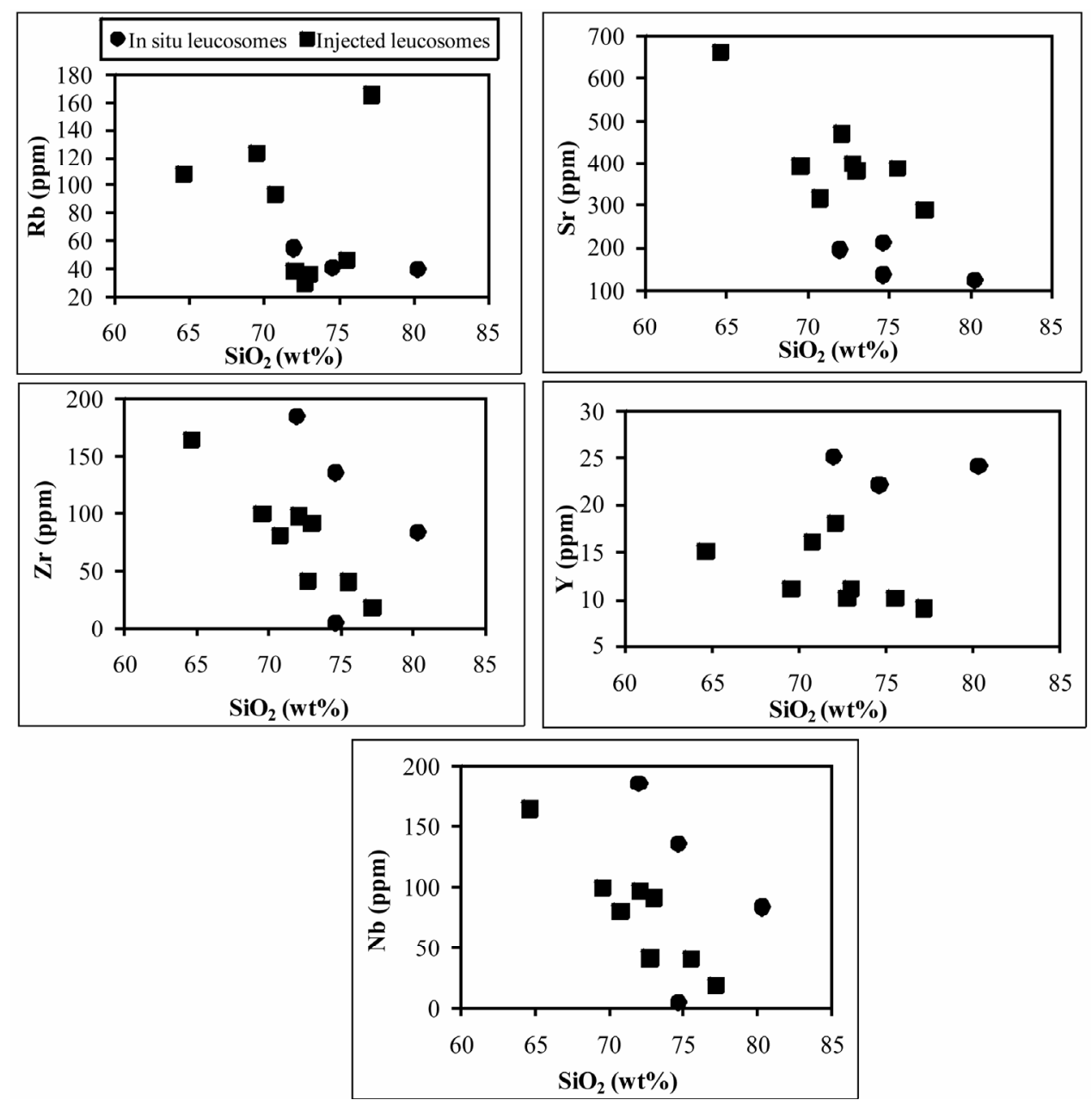

Figure 10. Harker diagrams of selected trace elements. Symbols as in Figure 6.

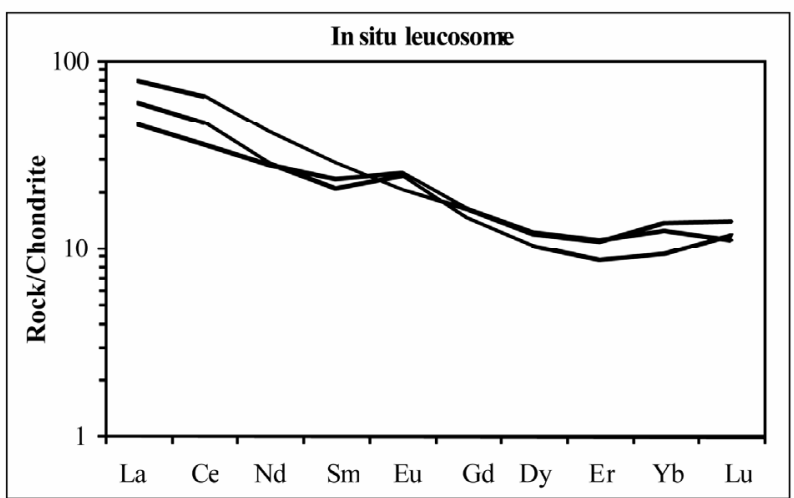

(a)

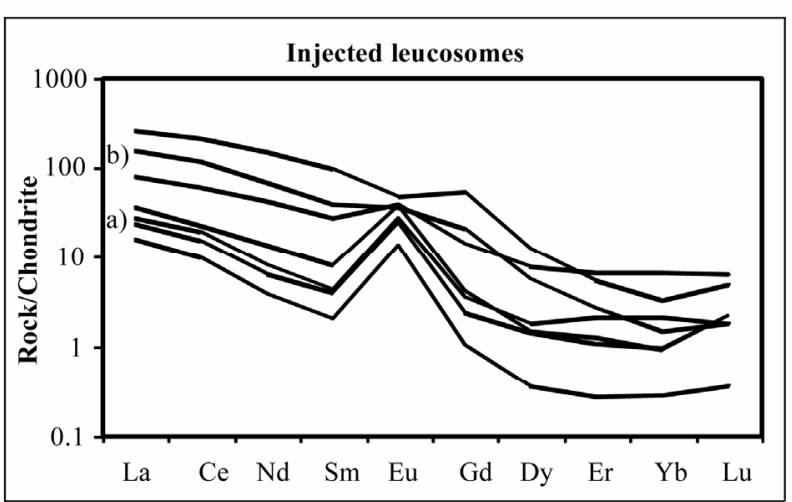

(b)

Figure 11. Chondrite-normalized REE patterns (the normalising values are from Jahn et al., 1978) for in situ leucosomes (a) and injected leucosomes (b).

deformed and metamorphosed rocks of the orogenic belt (along faults and shear zones) or occurs as syn to post-tectonic plutons [47-49]. Three main models have been proposed to explain the formation of peraluminous granitoids: 1) partial melting of quartzo-feldspathic or- thogneisses [50]; 2) reaction between basaltic melts and crustal rocks [51]; and 3) the spatial association and the presence of metasedimentary enclaves in the leucogranites suggesting an origin from partial melts of metasedimentary rocks $[13,52,53]$. 
Table 5. Electron microprobe analyses of monazite from Yaoundé leucosomes (sample OL3B). Monazite ages from single analyses are given with minimal error (see text).

\begin{tabular}{|c|c|c|c|c|c|c|c|c|c|c|c|c|c|c|c|c|c|c|}
\hline Sample & & & & & & & & & OL: & & & & & & & & & \\
\hline No & $\mathrm{SiO}_{2}$ & $\mathrm{I}_{2} \mathrm{O}_{3}$ & $\mathbf{P}_{2} \mathbf{O}_{5}$ & aO & $\mathbf{L a}_{2} \mathbf{O}_{3}$ & $\mathrm{Ce}_{2} \mathrm{O}_{3}$ & $\mathbf{P r}_{2} \mathbf{O}_{3}$ & $\mathrm{Sm}_{2} \mathbf{O}_{3}$ & $\mathbf{N d}_{2} \mathbf{O}_{3}$ & $\mathbf{E} \mathbf{u}_{2} \mathbf{O}_{3}$ & $\mathbf{G d}_{2} \mathbf{O}_{3}$ & $\mathrm{ThO}_{2}$ & $\mathbf{U O}_{2}$ & PbO & SrO & $\mathbf{Y}_{2} \mathbf{O}_{3}$ & Total & Age \\
\hline idmon & 2.33 & 0.00 & 24.79 & 0.16 & 7.10 & 24.15 & 3.72 & 5.15 & 16.17 & 0.00 & 2.58 & 13.82 & 0.54 & 0.33 & 0.00 & 1.41 & 102.25 & 489 \\
\hline 8 & 0.41 & 0.01 & 30.37 & 1.35 & 14.04 & 29.25 & 2.92 & 1.79 & 11.85 & 0.60 & 0.62 & 6.36 & 0.31 & 0.18 & 0.13 & 0.01 & 100.17 & 559 \\
\hline 9 & 0.28 & 0.00 & 30.38 & 1.31 & 14.51 & 29.11 & 2.86 & 2.05 & 11.79 & 0.68 & 1.05 & 5.04 & 0.83 & 0.19 & 0.16 & 0.34 & 100.56 & 565 \\
\hline 10 & 0.31 & 0.00 & 29.93 & 1.34 & 14.44 & 28.92 & 3.08 & 1.95 & 12.08 & 0.65 & 0.94 & 5.48 & 0.67 & 0.20 & 0.15 & 0.23 & 100.34 & 596 \\
\hline 11 & 0.32 & 0.00 & 29.98 & 1.35 & 13.89 & 29.41 & 3.04 & 1.91 & 12.36 & 0.59 & 0.71 & 6.03 & 0.34 & 0.19 & 0.13 & 0.01 & 100.26 & 631 \\
\hline 12 & 0.42 & 0.00 & 29.83 & 1.43 & 37 & 29.07 & 2.8 & 1. & 11 & 0.52 & 0.70 & 3 & 0.37 & 0 & 0.14 & 4 & 9.61 & 0 \\
\hline 13 & 0.46 & 03 & 29.19 & 1.41 & 13.74 & 28.94 & 3.28 & 1.91 & 13.00 & 0.58 & 0.70 & 6.48 & 0.35 & 0.18 & 0.14 & 0.01 & 100.41 & 563 \\
\hline 15 & 0.46 & 0.01 & 30.05 & 1.35 & 14.13 & 29.16 & 3.11 & 1.01 & 12.45 & 0.62 & 0.60 & 6.16 & 0.29 & 0.17 & 0.15 & 0.01 & 100.51 & 550 \\
\hline 17 & 59 & 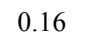 & 29.39 & 1.38 & 14.00 & 28.02 & 3.07 & 1.95 & 12.27 & 0.64 & 1.04 & 5.36 & 0.43 & 0.17 & 0.15 & 0.07 & 98.70 & 602 \\
\hline 18 & 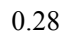 & 0.05 & 30.08 & 1.23 & 14. & 28.62 & 2. & 1.84 & 11.34 & 0.66 & 0. & 5.41 & 0.40 & 7 & 5 & 0 & 4 & 0 \\
\hline 19 & ? & 0.05 & 29.78 & 1.28 & 14.37 & 28.53 & 2.8 & 1.3 & 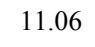 & 0.69 & 1. & 3 & 0. & 0 & & & & 597 \\
\hline 20 & 32 & 0.11 & 30.41 & 1.25 & 14.48 & 28.93 & 3.13 & 1.96 & 12.20 & 0.68 & 0.96 & 5.24 & 0.45 & 0.18 & 0.15 & 0.09 & 100.54 & 613 \\
\hline 21 & 0.26 & 0.05 & 26.43 & 0.94 & 8.92 & 19.45 & 2.07 & 1.13 & 7.59 & 0.42 & 0.54 & 3.99 & 0.33 & 0.13 & 0.12 & 0.10 & 72.47 & 607 \\
\hline 22 & 0.29 & 0.06 & 25.35 & 1.01 & 10.55 & 19.23 & 2.07 & 1.1 & 7.94 & 0.50 & 0.57 & 4.20 & 0.81 & 0.17 & 0.15 & 0.05 & 12 & 565 \\
\hline 23 & 0.26 & 0.09 & 30.18 & 0.83 & 16.22 & 30.10 & 3.00 & 1.8 & 11.79 & 0.67 & 1.10 & 2.44 & 0.77 & 0.13 & 0.15 & 0.16 & 99.72 & 615 \\
\hline 24 & 0.33 & 0.05 & 29.92 & 1.29 & 14.11 & 28.29 & 2.9 & 2.0 & 11.98 & 070 & 1.03 & 52 & 0.50 & 0.18 & 15 & 0.06 & 99.02 & 605 \\
\hline 25 & 0.32 & 0.03 & 29.84 & 1.28 & 14.28 & 28.69 & 2.79 & 1.95 & 11.52 & 0.65 & 1.06 & 5.53 & 0.47 & 0.17 & 0.13 & 0.08 & 98.81 & 572 \\
\hline 26 & 0.33 & 0.02 & 30.37 & 1.40 & 14.25 & 28.50 & 3.02 & 1.89 & 12.46 & 0.67 & 1.05 & 5.96 & 0.50 & 0.20 & 0.13 & 0.07 & 100.82 & 611 \\
\hline 27 & 0.27 & 0.01 & 30.13 & 1.38 & 14.25 & 28.66 & 2.88 & 1.84 & 11.56 & 0.62 & 1.01 & 6.00 & 0.49 & 0.20 & 0.13 & 0.07 & 99.48 & 606 \\
\hline 28 & 0.32 & 0.02 & 29.69 & 1.39 & 14.27 & 28.43 & 2.91 & 1.88 & 11.67 & 0.65 & 1.01 & 6.08 & 0.50 & 0.19 & 0.14 & 0.09 & 99.21 & 579 \\
\hline 29 & 0.26 & 0.02 & 25.10 & 1.04 & 10.06 & 19.37 & 2.04 & 1.15 & 7.56 & 0.42 & 0.61 & 4.83 & 0.39 & 0.15 & 0.14 & 0.06 & 73.18 & 576 \\
\hline 30 & 0.41 & 0.04 & 28.57 & 1.39 & 14.21 & 28.43 & 3.04 & 1.83 & 12.35 & 0.69 & 1.06 & 6.06 & 0.49 & 0.20 & 0.16 & 0.11 & 99.05 & 615 \\
\hline 31 & 0.29 & 0.02 & 29.98 & 1.37 & 14.60 & 28.91 & 2.93 & 1.83 & 11.82 & 0.66 & 1.01 & 5.66 & 0.48 & 0.19 & 0.16 & 0.10 & 100.00 & 616 \\
\hline 32 & 0.33 & 0.03 & 30.05 & 1.28 & 14.40 & 28.94 & 3.07 & 1.74 & 12.05 & 0.64 & 1.01 & 5.59 & 0.42 & 0.17 & 0.14 & 0.10 & 99.95 & 573 \\
\hline 33 & 0.33 & 0.01 & 29.83 & 1.40 & 14. & 28. & 3.0 & 1.7 & 1 & 0.65 & 1.01 & 97 & 0 & 0.20 & 5 & 0.09 & 65 & 596 \\
\hline 43 & 0 & 007 & 30.35 & 1 & 14. & 29.40 & 2.9 & 1.64 & 1 & 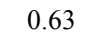 & 0.76 & 5 & 8 & 8 & 2 & 5 & & 628 \\
\hline 45 & 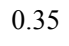 & 01 & 30.25 & 20 & 14.14 & 29.54 & 2.99 & 1.8 & 12.24 & 0.63 & 0.75 & 0.00 & 0.0 & 0.18 & 0.14 & 0.02 & & 609 \\
\hline 47 & 0.37 & 0.02 & 30.53 & 1.28 & 14.23 & 29.22 & 2.93 & 1.73 & 11.93 & 0.64 & 0.96 & 5.35 & 0.69 & 0.20 & 0.12 & 0.13 & 100.32 & 602 \\
\hline 48 & 30 & 11 & 29.94 & 1.19 & 14.37 & 29.04 & 3.03 & 1.9 & 11.83 & 0.67 & 0.97 & 5.09 & 0.43 & 0.16 & 0.14 & 0.10 & & 594 \\
\hline 50 & 0.28 & 0.07 & 29.99 & 1.24 & 14.66 & 29.05 & 2.91 & 1.98 & 11.80 & 0.78 & 0.97 & 5.12 & 0.68 & 0.19 & 0.15 & 0.25 & 100.10 & 608 \\
\hline 82 & 0.29 & 0.01 & 30.38 & 1.24 & 14.37 & 28.64 & 3.06 & 1.91 & 12.33 & 0.77 & 1.14 & 4.73 & 0.79 & 0.18 & 0.14 & 0.57 & 100.55 & 581 \\
\hline 52 & 0.29 & 0.10 & 29.96 & 1.24 & 14.41 & 29.18 & 3.19 & 1.96 & 12.27 & 0.64 & 0.90 & 5.37 & 0.38 & 0.17 & 0.14 & 0.05 & 100.23 & 615 \\
\hline 73 & 0.29 & 0.03 & 30.17 & 1.27 & 14.29 & 28.44 & 2.91 & 1.79 & 11.84 & 0.76 & 1.09 & 4.97 & 0.84 & 0.19 & 0.16 & 0.57 & 99.61 & 578 \\
\hline 74 & 0.20 & 0.01 & 29.74 & 0.64 & 14.90 & 29.46 & 3.03 & 1.99 & 11.62 & 0.89 & 1.44 & 2.31 & 0.71 & 0.13 & 0.15 & 0.69 & 97.89 & 638 \\
\hline 75 & 0.33 & 0.02 & 29.84 & 1.41 & 14.46 & 28.00 & 3.00 & 1.86 & 11.59 & 0.81 & 0.98 & 6.03 & 0.90 & 0.22 & 0.16 & 0.26 & 99.85 & 572 \\
\hline 76 & 0.21 & 0.00 & 30.13 & 0.75 & 14.51 & 29.50 & 3.13 & 1.96 & 12.04 & 0.94 & 1.34 & 2.81 & 0.86 & 0.14 & 0.15 & 0.72 & 99.19 & 574 \\
\hline 1 & 0.35 & 0.00 & 3 & 1.41 & 14 & 28 & 2. & 1. & 1 & 0 & 0 . & 5.71 & 0. & 0 & 0 & 0 & 91 & 585 \\
\hline 79 & 0.22 & 0.00 & 30.41 & 0.70 & 14.81 & 29.01 & 3.04 & 1.92 & 11.96 & 0.88 & 1.30 & 2.54 & 0.94 & 0.14 & 0.14 & 0.88 & 98.87 & 569 \\
\hline 81 & 0.26 & 0.02 & 30.58 & 1.22 & 14.54 & 28.61 & 3.12 & 1.85 & 12.10 & 0.78 & 1.17 & 4.84 & 0.82 & 0.20 & 0.13 & 0.57 & 100 & 612 \\
\hline 49 & 0.33 & 0.10 & 28.34 & 1.24 & 14.65 & 28.40 & 2.96 & 1.80 & 11 & 0.69 & 0.99 & 5.14 & 0.68 & 0.20 & 0.17 & 0.42 & 6 & 625 \\
\hline 51 & 0.35 & 0.11 & 29.19 & 1.27 & 14.40 & 29.07 & 2.93 & 1.77 & 12.47 & 0.66 & 0.73 & 5.66 & 0.31 & 0.18 & 0.14 & 0.03 & 6 & 639 \\
\hline 16 & 0.32 & 0.00 & 29.97 & 1.31 & 14.24 & 29.01 & . & 2.04 & 12.72 & 0.63 & 1.00 & 5.68 & 0.37 & 0.19 & 0.15 & 2 & 00.79 & 14 \\
\hline 34 & 0.29 & 0.01 & 24.50 & 0.93 & 9.62 & 20.90 & 2.22 & 0.92 & 8.01 & 0.47 & 0.75 & 4.94 & 0.30 & 0.16 & 0.16 & 0.09 & 74.98 & s \\
\hline 42 & 0.35 & 0.01 & 30.07 & 1.38 & 13.79 & 28.77 & 3.00 & 1.86 & 12.51 & 0.61 & 0.75 & 6.19 & 0.37 & 0.20 & 0.14 & 0.05 & 100.04 & 650 \\
\hline 44 & 0.38 & 0.02 & 30.15 & 1.27 & 14.27 & 29.58 & 2.93 & 1.67 & 11.81 & 0.61 & 0.72 & 5.71 & 0.37 & 0.19 & 0.14 & 0.04 & 99.87 & 661 \\
\hline 78 & 0.36 & .01 & 29.95 & 19 & 14.28 & 28.34 & 3.06 & 1.88 & 11.68 & 0.69 & 1.31 & 5.15 & 0.52 & 0.19 & 0.14 & 0.51 & 99.26 & 645 \\
\hline
\end{tabular}



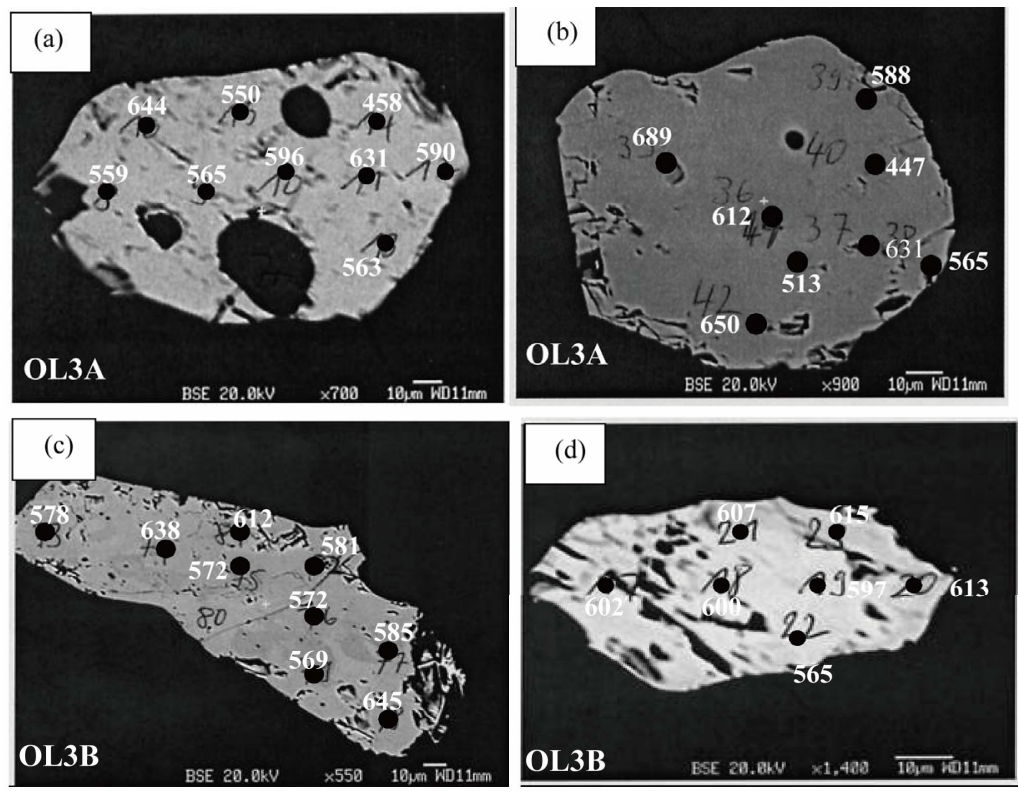

Figure 12. Backscattered electron images of selected dated monazite crystals in Yaoundé leucosomes: (a) and (b) Globular shape crystals; (c) and (d) Prismatic crystals.

Table 6. LA-ICP-MS U-Pb results for zircons from leucosomes in metapelite of the Yaoundé series.

\begin{tabular}{|c|c|c|c|c|c|c|c|c|c|c|c|c|c|}
\hline \multirow{2}{*}{ Sample } & \multicolumn{6}{|c|}{ Isotopic ratios } & \multicolumn{6}{|c|}{ Apparent ages } & \multirow{2}{*}{ rho } \\
\hline & ${ }^{207} \mathrm{~Pb} /{ }^{206} \mathrm{~Pb}$ & $\% 2 \sigma$ & ${ }^{207} \mathbf{P b} /{ }^{205} \mathbf{U}$ & $2 \sigma$ & ${ }^{206} \mathbf{P b} /{ }^{208} \mathbf{U}$ & $2 \sigma$ & ${ }^{207} \mathrm{~Pb} /{ }^{206} \mathrm{~Pb}$ & $2 \sigma$ & ${ }^{207} \mathbf{P b} /{ }^{205} \mathbf{U}$ & $2 \sigma$ & ${ }^{206} \mathbf{P b} /{ }^{208} \mathbf{U}$ & $2 \sigma$ & \\
\hline Z6 & 0.0605 & 0.8766 & 0.8432 & 3.19 & 0.1011 & 3.07 & 620.9815 & 18.91 & 620.8974 & 14.82 & 620.8744 & 18.16 & 0.96 \\
\hline Z9 & 0.0647 & 1.0745 & 1.0648 & 2.08 & 0.1194 & 1.78 & 763.8462 & 22.64 & 736.1893 & 10.87 & 727.1329 & 12.22 & 0.86 \\
\hline Z11 & 0.0602 & 0.8210 & 0.9097 & 1.95 & 0.1096 & 1.77 & 610.7711 & 17.74 & 656.8983 & 9.44 & 670.4097 & 11.27 & 0.91 \\
\hline Z14 & 0.0615 & 0.9516 & 0.8467 & 2.26 & 0.0998 & 2.04 & 657.5927 & 20.41 & 622.8499 & 10.50 & 613.3286 & 11.96 & 0.91 \\
\hline Z16 & 0.0597 & 1.0440 & 0.8588 & 2.07 & 0.1044 & 1.79 & 592.0281 & 22.63 & 629.4851 & 9.72 & 639.9615 & 10.90 & 0.86 \\
\hline Z18 & 0.0599 & 1.3962 & 0.9419 & 2.61 & 0.1141 & 2.20 & 599.6740 & 30.23 & 673.8698 & 12.85 & 696.2775 & 14.55 & 0.84 \\
\hline $\mathrm{Z} 23$ & 0.0598 & 1.1160 & 0.8539 & 3.77 & 0.1036 & 3.61 & 595.9765 & 24.18 & 626.8027 & 17.65 & 635.3784 & 21.82 & 0.96 \\
\hline $\mathrm{Z} 27$ & 0.0602 & 0.8331 & 0.8535 & 3.09 & 0.1029 & 2.98 & 609.2004 & 18.01 & 626.5621 & 14.46 & 631.3819 & 17.91 & 0.96 \\
\hline Z28 & 0.0601 & 0.9413 & 0.9017 & 3.86 & 0.1087 & 3.75 & 608.8288 & 20.35 & 652.6611 & 18.59 & 665.4089 & 23.68 & 0.97 \\
\hline Z29 & 0.0604 & 1.1882 & 0.8103 & 2.50 & 0.0973 & 2.19 & 618.0647 & 25.65 & 602.6232 & 11.34 & 598.5263 & 12.54 & 0.88 \\
\hline $\mathrm{Z} 31$ & 0.0600 & 5.5132 & 0.8380 & 3.95 & 0.1013 & 3.49 & 603.6146 & 115.02 & 618.0268 & 12.31 & 621.9688 & 20.77 & 0.88 \\
\hline Z33 & 0.0578 & 3.2449 & 0.8111 & 2.45 & 0.1017 & 1.69 & 523.8707 & 69.62 & 603.0479 & 6.46 & 624.3219 & 10.14 & 0.69 \\
\hline Z37 & 0.0602 & 1.0918 & 0.8647 & 3.04 & 0.1042 & 2.83 & 609.3628 & 23.60 & 632.6981 & 14.29 & 639.2483 & 17.23 & 0.93 \\
\hline Z38 & 0.0593 & 3.7630 & 0.8331 & 2.70 & 0.1019 & 2.16 & 577.5185 & 79.74 & 615.3266 & 7.25 & 625.6504 & 12.97 & 0.80 \\
\hline
\end{tabular}

The leucosomes of the Yaoundé series are characterized by: 1) their peraluminous affinity; 2) their $\mathrm{Rb} / \mathrm{Zr}$ weak ratios $(0.2-6.38)$ characteristic of granites of crustal origin [54]; 3) the relative low content in $\mathrm{Sr}(1.93$ 499), the relative enrichment in $\mathrm{K}_{2} \mathrm{O}(1.52-5.18)$ and the relatively low contents in $\mathrm{CaO}$ (1.24 - 3.04) characteristic of the rocks of pelitic origin [55]. Their chemical compo- sition is similar to S-type granite from S-type Transamazonian and Hercynian peraluminous leucogranites [55, $56]$ and to that of melts produced experimentally from sedimentary protoliths $[57,58]$. The enrichment in alkali in relation with $\mathrm{CaO}$ is characteristic of calc-alkaline Cordillera type granitoids [59]. In molar diagram $\mathrm{CaO} /(\mathrm{MgO}+\mathrm{FeOt})$ vs $\mathrm{Al}_{2} \mathrm{O}_{3} /(\mathrm{MgO}+\mathrm{FeOt})$ of Altherr 


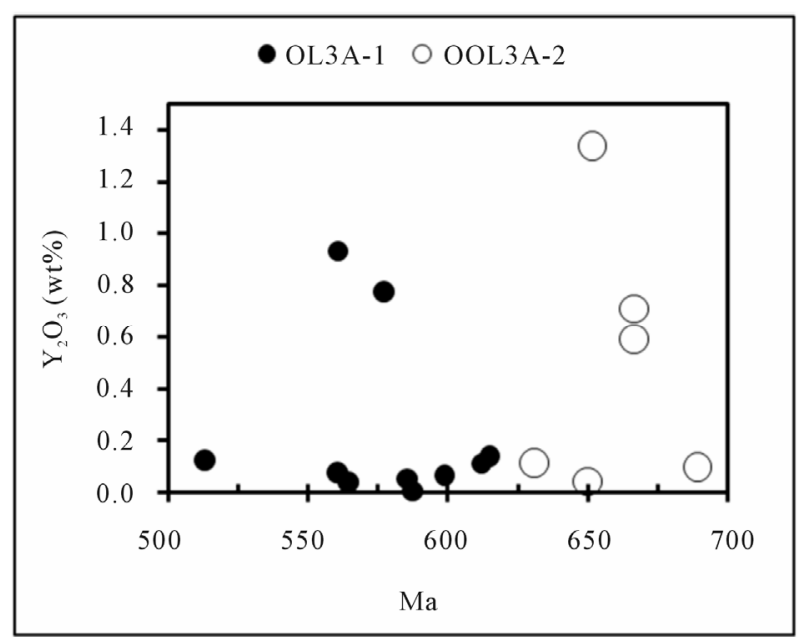

(a)

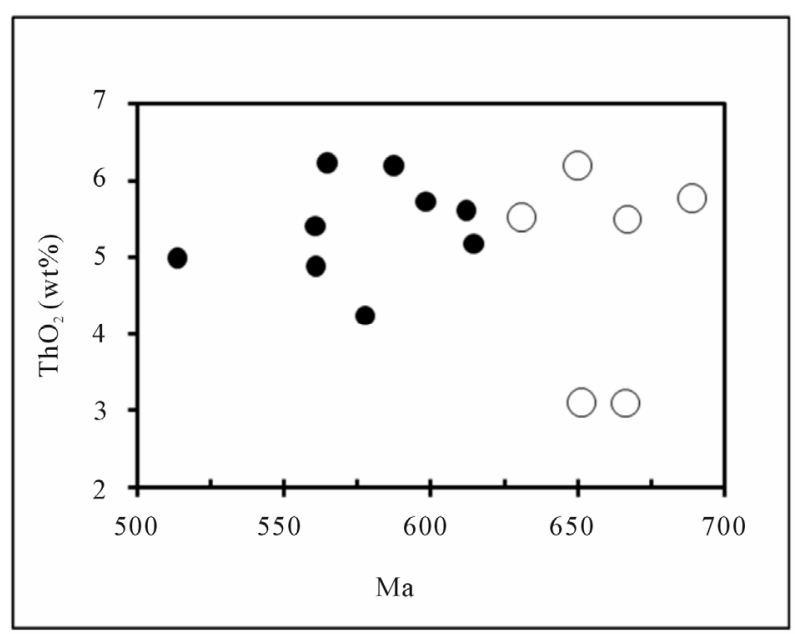

(b)

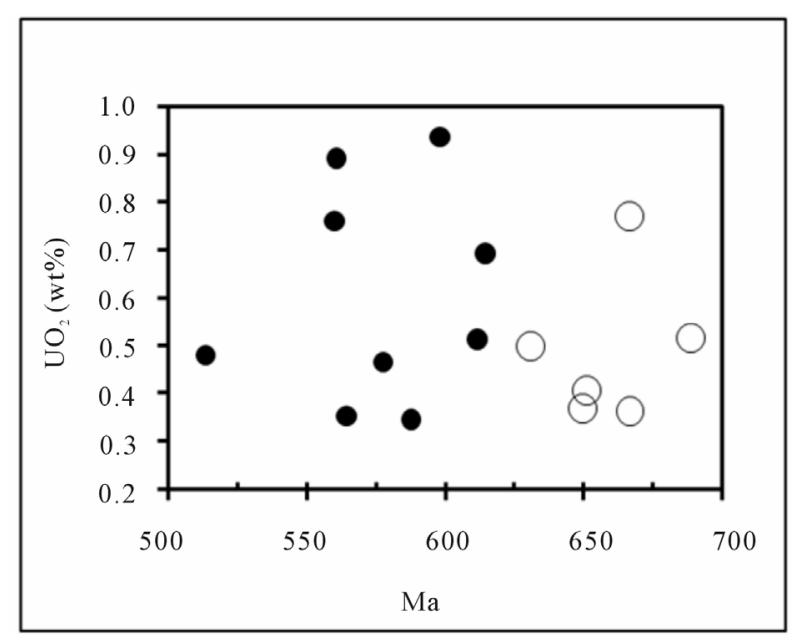

(c)

Figure 13. Mineral chemistry of monazites vs Th-U-Pb chemical ages of sample OL3A. (a) $\mathrm{Y}_{2} \mathrm{O}_{3}$ of monazites vs age; (b) $\mathrm{ThO}_{2}$ of monazite vs age; (c) $\mathrm{UO}_{2}$ of monazites vs age.

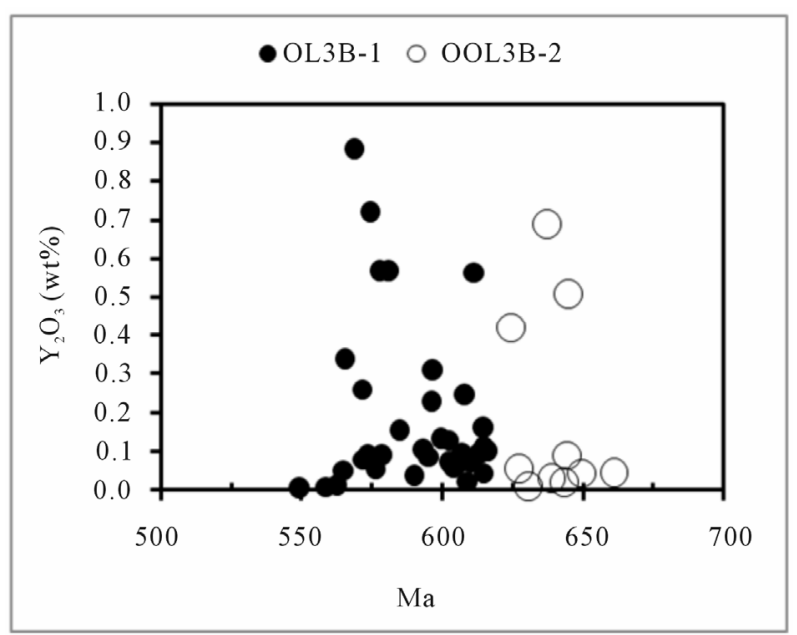

(a)

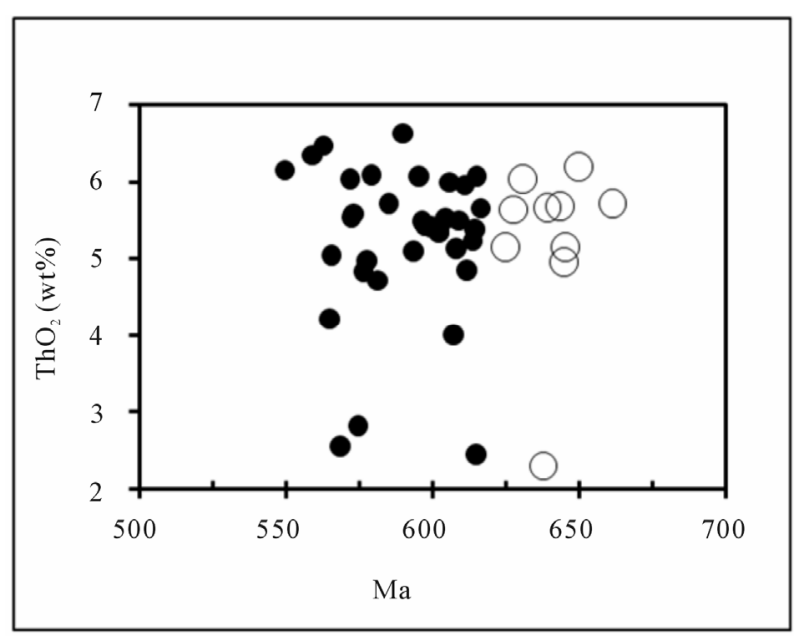

(b)

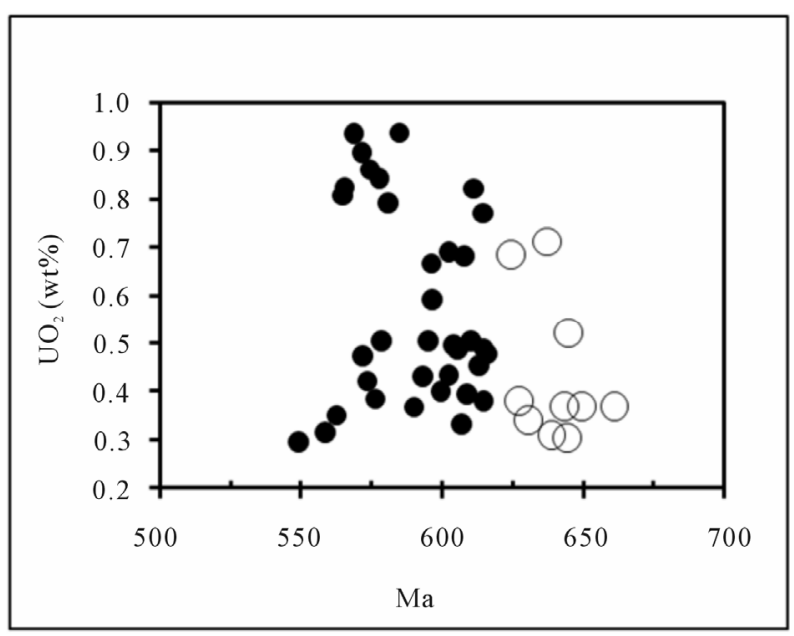

(c)

Figure 14. Mineral chemistry of monazites vs Th-U-Pb chemical ages of sample $\mathrm{OL3B}$. (a) $\mathrm{Y}_{2} \mathrm{O}_{3}$ of monazites vs age; (b) $\mathrm{ThO}_{2}$ of monazite vs age; (c) $\mathrm{UO}_{2}$ of monazites vs age. 


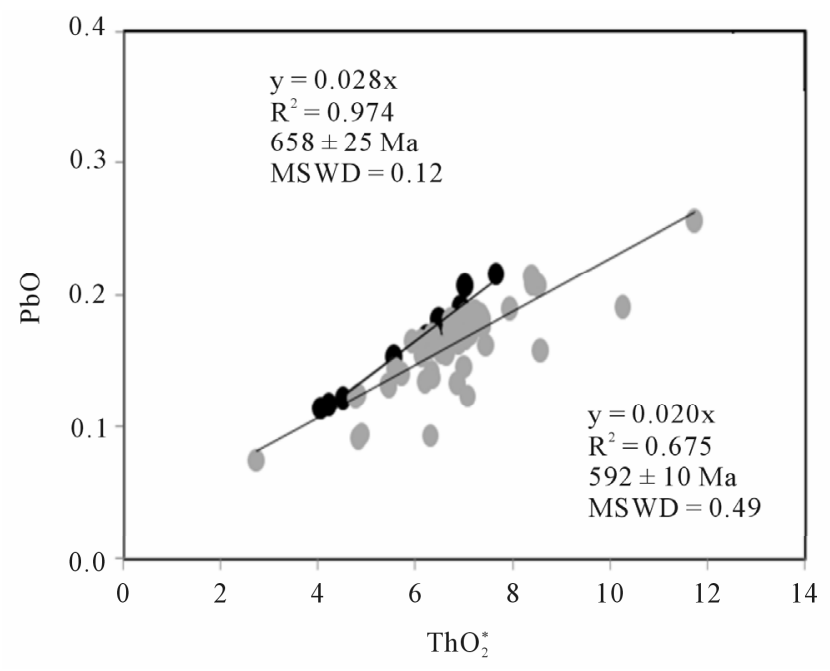

(a)

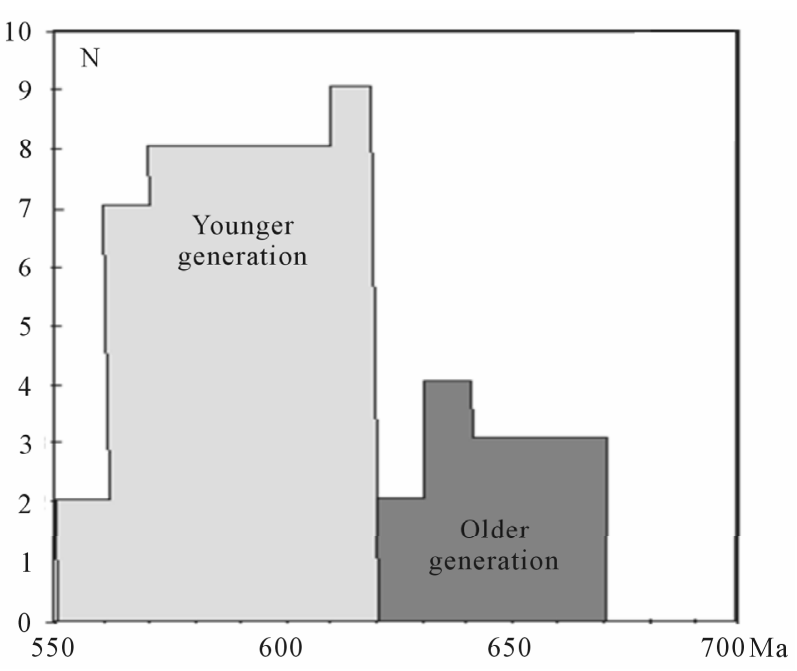

(b)

Figure 15. (a) Th-U-Pb CHIME model ages for Yaoundé leucosomes. Total $\mathrm{PbO}_{\mathrm{vs}} \mathrm{ThO}_{2}^{\star} \quad$ (wt $\%$ ) isochron diagram; $\mathrm{ThO}_{2}^{\star}$ $=\mathrm{ThO}_{2}+\mathrm{UO}_{2}$ equivalents expressed as $\mathrm{ThO}_{2}$, after [46]. Isochron age derived from these diagrams broadly match weighted average ages calculated for the rocks according to [34]; (b) Histogram view of EMP-Th-U-Pb monazite ages.

Table 7. LA-ICP-MS U-Pb results for zircons from leucosomes in metabasite of the Yaoundé series.

\begin{tabular}{|c|c|c|c|c|c|c|c|c|c|c|c|c|}
\hline \multirow{2}{*}{ Sample } & \multicolumn{6}{|c|}{ Isotopic ratios } & \multicolumn{6}{|c|}{ Apparent ages } \\
\hline & ${ }^{207} \mathbf{P b} /{ }^{206} \mathbf{P b}$ & $2 \sigma$ & ${ }^{207} \mathrm{~Pb} /{ }^{205} \mathrm{U}$ & $2 \sigma$ & ${ }^{206} \mathbf{P b} /{ }^{208} \mathrm{U}$ & $2 \sigma$ & ${ }^{207} \mathbf{P b} /{ }^{206} \mathbf{P b}$ & $2 \sigma$ & ${ }^{207} \mathbf{P b} /{ }^{205} \mathbf{U}$ & $2 \sigma$ & ${ }^{206} \mathbf{P b} /{ }^{208} \mathbf{U}$ & $2 \sigma$ \\
\hline $\mathrm{Z1}$ & 0.0619 & 0.99 & 0.7891 & 2.18 & 0.0924 & 1.95 & 671.1023 & 21.19 & 590.6603 & 9.78 & 569.9372 & 10.61 \\
\hline $\mathrm{Z} 2$ & 0.0613 & 0.95 & 0.8539 & 2.12 & 0.1009 & 1.89 & 651.3840 & 20.50 & 626.7634 & 9.92 & 619.9625 & 11.19 \\
\hline $\mathrm{Z} 2$ nuc & 0.0616 & 0.97 & 0.8047 & 2.17 & 0.0947 & 1.94 & 660.5042 & 20.81 & 599.4976 & 9.82 & 583.4934 & 10.82 \\
\hline $\mathrm{Z3}$ & 0.0624 & 1.64 & 0.8284 & 3.68 & 0.0962 & 3.29 & 689.4344 & 35.00 & 612.6979 & 16.91 & 592.1415 & 18.61 \\
\hline $\mathrm{Z4}$ & 0.0615 & 1.03 & 0.8250 & 2.43 & 0.0972 & 2.20 & 657.8133 & 22.09 & 610.8348 & 11.16 & 598.2421 & 12.58 \\
\hline $\mathrm{Z} 5$ & 0.0617 & 0.79 & 0.8257 & 1.94 & 0.0971 & 1.77 & 663.6617 & 16.94 & 611.2062 & 8.89 & 597.1463 & 10.08 \\
\hline Z6 & 0.0627 & 0.72 & 0.8322 & 1.82 & 0.0962 & 1.68 & 699.7667 & 15.28 & 614.8545 & 8.41 & 592.0477 & 9.48 \\
\hline $\mathrm{Z7}$ & 0.0613 & 1.66 & 0.8491 & 3.84 & 0.1005 & 3.46 & 649.7675 & 35.65 & 624.1353 & 17.91 & 617.0873 & 20.38 \\
\hline $\mathrm{Z} 8$ & 0.0605 & 0.89 & 0.8205 & 1.91 & 0.0984 & 1.69 & 620.1877 & 19.29 & 608.3527 & 8.74 & 605.1796 & 9.74 \\
\hline Z9 & 0.0613 & 1.00 & 0.8383 & 2.23 & 0.0991 & 1.99 & 651.4618 & 21.54 & 618.2209 & 10.31 & 609.1809 & 11.56 \\
\hline $\mathrm{Z} 10$ & 0.0610 & 0.70 & 0.8326 & 1.63 & 0.0990 & 1.47 & 638.4511 & 15.04 & 615.0440 & 7.51 & 608.7049 & 8.54 \\
\hline Z11 & 0.0612 & 1.39 & 0.7908 & 3.18 & 0.0938 & 2.86 & 644.7045 & 29.90 & 591.6114 & 14.27 & 577.8623 & 15.82 \\
\hline $\mathrm{Z} 12$ & 0.0617 & 0.89 & 0.8647 & 1.90 & 0.1016 & 1.68 & 663.8725 & 19.06 & 632.7046 & 8.96 & 624.0163 & 10.00 \\
\hline $\mathrm{Z} 13$ & 0.0622 & 0.70 & 0.8577 & 1.49 & 0.1000 & 1.31 & 681.9553 & 15.01 & 628.8560 & 6.96 & 614.1906 & 7.66 \\
\hline Z16 & 0.0611 & 0.65 & 0.8468 & 1.40 & 0.1005 & 1.23 & 642.4081 & 14.03 & 622.8909 & 6.50 & 617.5314 & 7.26 \\
\hline Z17 & 0.0607 & 1.95 & 0.8335 & 4.34 & 0.0996 & 3.87 & 629.0979 & 42.02 & 615.5313 & 20.02 & 611.8495 & 22.61 \\
\hline
\end{tabular}

et al. [60], the in situ leucosomes are plotted in the field of partial melts from metapelite source whereas the injected leucosomes are plotted in the field of partial melt from metagreywacke source (Figure 20). These sources, which are predominantly found in the upper part of the continental crust, allow us to confirm that the source of in situ leucosomes was the metapelitic host rocks and to suggest that the injected leucosomes are originated 
Table 8. LA-ICP-MS U-Pb results for no zoned zircons from leucosomes in metapelite of the Yaoundé series.

\begin{tabular}{|c|c|c|c|c|c|c|c|c|c|c|c|c|c|}
\hline \multirow{2}{*}{ Sample } & \multicolumn{6}{|c|}{ Isotopic ratios } & \multicolumn{6}{|c|}{ Apparent ages } & \multirow{2}{*}{ rho } \\
\hline & ${ }^{207} \mathbf{P b} /{ }^{206} \mathbf{P b}$ & $\% 2 \sigma$ & ${ }^{207} \mathrm{~Pb} /{ }^{205} \mathbf{U}$ & $2 \sigma$ & ${ }^{206} \mathbf{P b} /{ }^{208} \mathrm{U}$ & $2 \sigma$ & ${ }^{207} \mathbf{P b} /{ }^{206} \mathbf{P b}$ & $2 \sigma$ & ${ }^{207} \mathrm{~Pb} /{ }^{205} \mathrm{U}$ & $2 \sigma$ & ${ }^{206} \mathrm{~Pb} /{ }^{208} \mathbf{U}$ & $2 \sigma$ & \\
\hline $\mathrm{Z1}$ & 0.1200 & 0.99 & 5.1092 & 3.73 & 0.3088 & 3.6 & 1955.922 & 17.64 & 1837.6284 & 31.68 & 1735.0134 & 54.73 & 0.96 \\
\hline $\mathrm{Z2}$ & 0.0674 & 1.37 & 1.2642 & 2.56 & 0.1360 & 2.17 & 850.7457 & 28.38 & 829.7947 & 14.52 & 821.9938 & 16.71 & 0.85 \\
\hline $\mathrm{Z} 5$ & 0.0717 & 1.43 & 1.4640 & 3.14 & 0.1481 & 2.79 & 977.7781 & 29.07 & 915.6620 & 18.92 & 890.1041 & 23.23 & 0.89 \\
\hline UQZ & 0.0787 & 1.16 & 2.1010 & 2.28 & 0.1936 & 1.97 & 1164.735 & 22.89 & 1149.1404 & 15.7 & 1140.8935 & 20.57 & 0.86 \\
\hline $\mathrm{Z} 10$ & 0.0749 & 1.42 & 1.6876 & 2.46 & 0.1634 & 2.01 & 1066.207 & 28.5 & 1003.8718 & 15.67 & 975.5618 & 18.17 & 0.82 \\
\hline Z13 & 0.0616 & 5.10 & 1.1773 & 3.68 & 0.1387 & 3.17 & 659.0272 & 105.7 & 790.0483 & 11.03 & 837.2553 & 24.98 & 0.86 \\
\hline Z15 & 0.0719 & 1.16 & 1.5949 & 5.18 & 0.1608 & 5.05 & 983.6733 & 23.53 & 968.2228 & 32.32 & 961.4305 & 45.09 & 0.97 \\
\hline $\mathrm{Z} 17$ & 0.0723 & 0.86 & 1.6499 & 1.7 & 0.1654 & 1.47 & 995.2298 & 17.48 & 989.5054 & 10.78 & 986.9260 & 13.47 & 0.86 \\
\hline Z19 & 0.0768 & 1.37 & 1.8392 & 3.69 & 0.1737 & 3.42 & 1115.352 & 27.33 & 1059.5748 & 24.26 & 1032.7020 & 32.68 & 0.93 \\
\hline $\mathrm{Z} 21$ & 0.1335 & 0.71 & 7.0269 & 1.95 & 0.3818 & 1.82 & 2144.12 & 12.34 & 2114.8390 & 17.35 & 2084.8607 & 32.4 & 0.93 \\
\hline $\mathrm{Z} 24$ & 0.0701 & 1.61 & 1.4446 & 2.45 & 0.1495 & 1.85 & 931.2847 & 32.98 & 907.6365 & 14.71 & 897.9478 & 15.52 & 0.76 \\
\hline $\mathrm{Z} 25$ & 0.0742 & 0.89 & 1.6954 & 2.29 & 0.1658 & 2.12 & 1046.221 & 17.86 & 1006.8130 & 14.65 & 988.8027 & 19.4 & 0.92 \\
\hline Z26 & 0.0722 & 0.82 & 1.6791 & 1.69 & 0.1687 & 1.48 & 991.733 & 16.62 & 1000.6451 & 10.77 & 1004.7177 & 13.78 & 0.88 \\
\hline $\mathrm{Z} 30$ & 0.0706 & 0.98 & 1.5056 & 2.17 & 0.1547 & 1.94 & 945.2829 & 20.05 & 932.6642 & 13.27 & 927.3334 & 16.77 & 0.89 \\
\hline Z34 & 0.0658 & 1.18 & 1.1546 & 2.07 & 0.1272 & 1.7 & 801.4074 & 24.78 & 779.4286 & 11.26 & 771.7750 & 12.36 & 0.82 \\
\hline Z35 & 0.0928 & 2.40 & 2.4133 & 3.74 & 0.1886 & 2.87 & 1483.716 & 45.39 & 1246.5718 & 26.85 & 1113.8944 & 29.38 & 0.77 \\
\hline
\end{tabular}

Table 9. LA-ICP-MS U-Pb results for zoned zircons from leucosomes in metapelite of the Yaoundé series.

\begin{tabular}{|c|c|c|c|c|c|c|c|c|c|c|c|c|c|}
\hline \multirow{2}{*}{ Sample } & \multicolumn{6}{|c|}{ Isotopic ratios } & \multicolumn{6}{|c|}{ Apparent ages } & \multirow{2}{*}{ rho } \\
\hline & ${ }^{207} \mathrm{~Pb} /{ }^{206} \mathrm{~Pb}$ & $\% 2 \sigma$ & ${ }^{207} \mathbf{P b} /{ }^{205} \mathbf{U}$ & $2 \sigma$ & ${ }^{206} \mathrm{~Pb} /{ }^{208} \mathrm{U}$ & $2 \sigma$ & ${ }^{207} \mathrm{~Pb} /{ }^{206} \mathrm{~Pb}$ & $2 \sigma$ & ${ }^{207} \mathrm{~Pb} /{ }^{205} \mathrm{U}$ & $2 \sigma$ & ${ }^{206} \mathrm{~Pb} /{ }^{208} \mathrm{U}$ & $2 \sigma$ & \\
\hline $\mathrm{Z3}$ rim & 0.0647 & 1.21 & 0.9043 & 3.64 & 0.1014 & 3.43 & 764.6318 & 25.51 & 654.0077 & 17.54 & 622.4003 & 20.35 & 0.94 \\
\hline Z4 core & 0.0752 & 0.82 & 1.7795 & 1.98 & 0.1716 & 1.8 & 1073.652 & 16.38 & 1037.9923 & 12.84 & 1021.1423 & 16.99 & 0.91 \\
\hline Z4 rim & 0.0524 & 6.32 & 0.6650 & 3.93 & 0.0921 & 2.13 & 301.5535 & 138.1 & 517.6816 & 12.1 & 567.9469 & 11.94 & 0.54 \\
\hline $\mathrm{Z7}$ core & 0.0756 & 1.38 & 1.7610 & 3.94 & 0.1690 & 3.69 & 1083.34 & 27.6 & 1031.1986 & 25.52 & 1006.7896 & 34.42 & 0.94 \\
\hline Z7 rim & 0.0620 & 1.27 & 0.8475 & 2.64 & 0.0991 & 2.32 & 674.7792 & 27.25 & 623.2645 & 12.32 & 609.1674 & 13.47 & 0.88 \\
\hline Z8 rim & 0.0604 & 2.30 & 0.8478 & 3.17 & 0.1018 & 2.18 & 617.074 & 49.6 & 623.4189 & 14.75 & 625.1686 & 12.99 & 0.69 \\
\hline Z8 core & 0.0763 & 2.64 & 1.4847 & 6.29 & 0.1410 & 5.71 & 1104.207 & 52.7 & 924.1597 & 38.14 & 850.5465 & 45.47 & 0.91 \\
\hline Z12 core & 0.0701 & 1.56 & 1.3590 & 4.58 & 0.1405 & 4.31 & 932.3045 & 31.94 & 871.4548 & 26.82 & 847.7063 & 34.25 & 0.94 \\
\hline Z12 rim & 0.0615 & 1.09 & 0.9102 & 2.43 & 0.1073 & 2.18 & 657.5111 & 23.39 & 657.1412 & 11.77 & 657.0335 & 13.59 & 0.89 \\
\hline Z20 core & 0.0724 & 0.81 & 1.7784 & 2.95 & 0.1782 & 2.84 & 996.8004 & 16.37 & 1037.6119 & 19.16 & 1057.0889 & 27.64 & 0.96 \\
\hline $\mathrm{Z} 20$ rim & 0.0603 & 1.26 & 0.7989 & 2.59 & 0.0961 & 2.26 & 614.6519 & 27.27 & 596.1838 & 11.69 & 591.3409 & 12.79 & 0.87 \\
\hline Z32 core & 0.0671 & 4.16 & 1.0508 & 2.97 & 0.1136 & 2.71 & 839.9745 & 84.22 & 729.2884 & 8.31 & 693.7953 & 17.9 & 0.91 \\
\hline Z32 rim & 0.0604 & 0.97 & 0.8606 & 1.76 & 0.1033 & 1.47 & 619.5192 & 20.92 & 630.4761 & 8.28 & 633.5354 & 8.885 & 0.84 \\
\hline Z36rim & 0.0732 & 1.11 & 1.6318 & 2.12 & 0.1618 & 1.8 & 1018.486 & 22.52 & 982.5622 & 13.34 & 966.5619 & 16.18 & 0.85 \\
\hline Z36 core & 0.0762 & 1.54 & 1.8670 & 2.6 & 0.1777 & 2.1 & 1100.841 & 30.76 & 1069.4846 & 17.21 & 1054.1738 & 20.41 & 0.81 \\
\hline
\end{tabular}




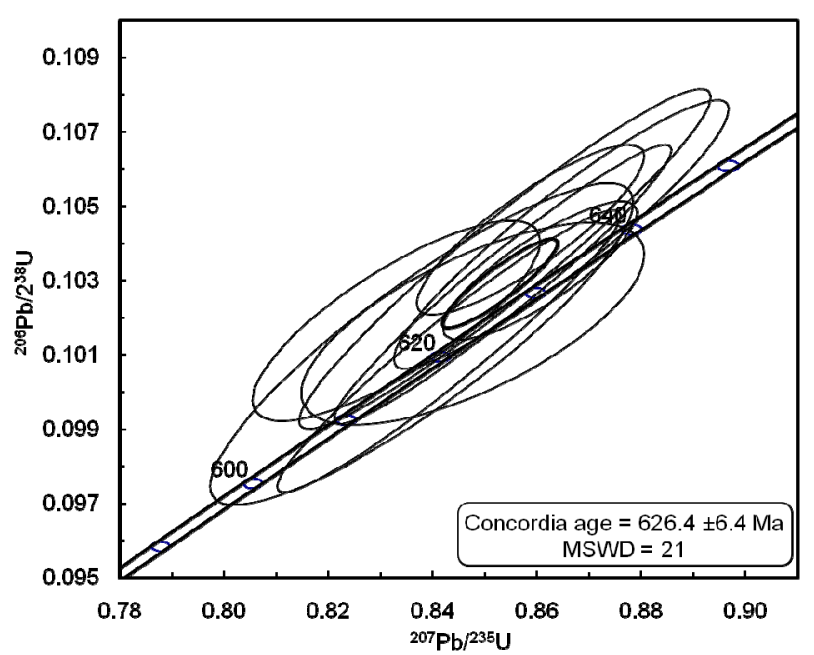

Figure 16. U-Pb Concordia diagram ages for zircons from leucosomes in metapelite of the Yaoundé series.

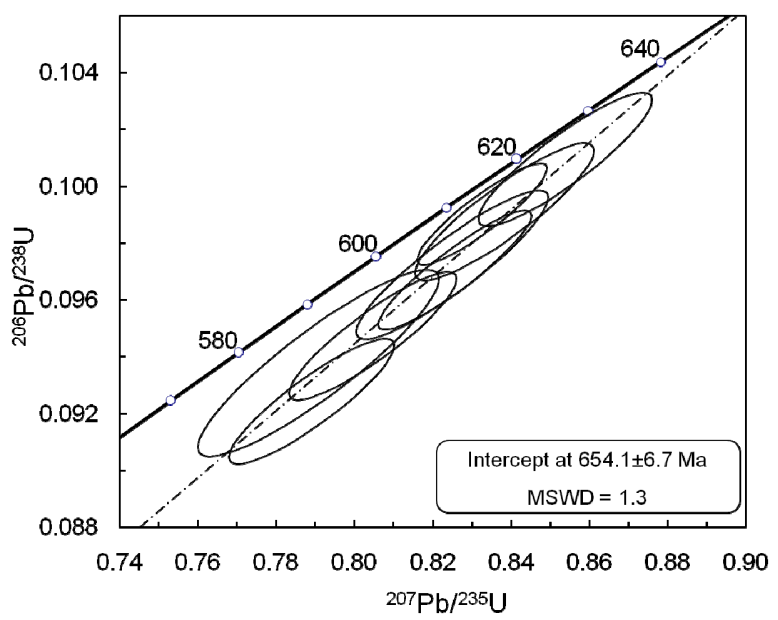

Figure 17. U-Pb Discordia diagram for zircons from leucosomes in metabasite of the Yaoundé series.

from melting of metagreywacke. The difference between the two types of leucosomes could be linked to the difference in the composition of their source and the probable contamination during transportation of the melting material (displacement and injection of magmatic liquids). Thus the melting phenomenon observed in the Yaoundé series has not only affected the metapelitic rocks of this series but also the metagreywacke of the upper part of the crust as proposed in the other domains of the PANEFB. The proposed source for the leucosome of theYaoundé series is similar to that for the AkumBamenda leucogranites [4] and for the two-mica granitoids of Bafoussam area [21].

\subsection{Comparison with the Granitoids of the PANEFB}

The leucosomes of the Yaoundé series are silica-rich

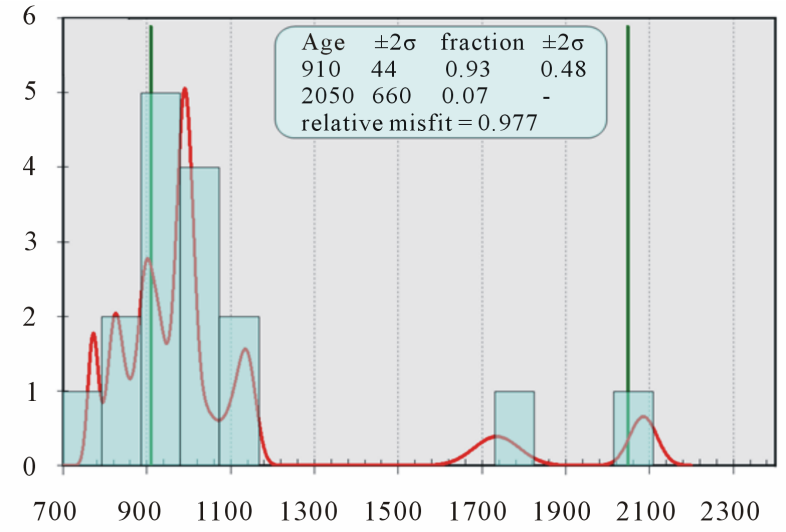

(a)

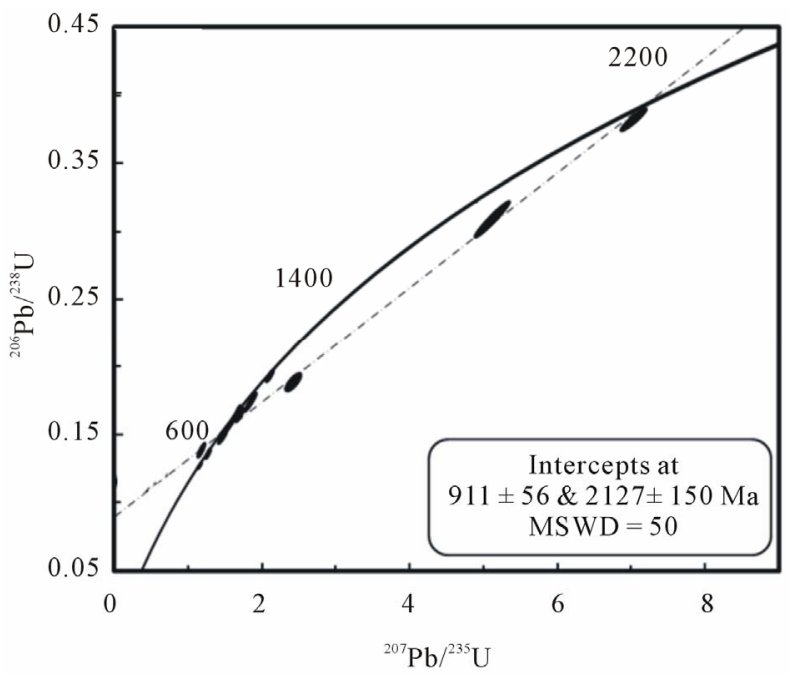

(b)

Figure 18. (a) Histogram of ages showing the different thermal event recorded by zoned zircons from leucosomes in metapelite of the Yaoundé series; (b) U-Pb Discordia diagram ages for these zircons.

(71.91 - $74.41 \mathrm{wt} \% \mathrm{SiO}_{2}$; Table 10). The alkali concentration $\left(\mathrm{Na}_{2} \mathrm{O}+\mathrm{K}_{2} \mathrm{O}=3.53-9.11 \mathrm{wt} \%\right)$ and the variable $\mathrm{K}_{2} \mathrm{O} / \mathrm{Na}_{2} \mathrm{O}$ ratios between 0.6 and 2 are characteristics of the high-K calc-alkaline to shoshonitic series (Figure 21(a)) as proposed for the granitoids of the central domain of the PANEFB [4,21-24,61-63]. The leucosomes of the Yaoundé series are peraluminous with the characteristics of S-type (in situ leucosomes) and I-type (injected leucosomes) granite. In the alumina index comparison diagram (Figure 21(b)), the in situ leucosomes show similar composition with Akum-Bamenda leucogranites [4] and two-mica granitoids of Bafoussam [21] whereas injected leucosomes are closer to the BanefoMvoutsaha granitoids [22] and to high-K calc-alkaline granitoids of Bapa-Batié [24]. These leucosomes can therefore be considered as peraluminous granite associated to the orogenic belt such as those described in [47- 


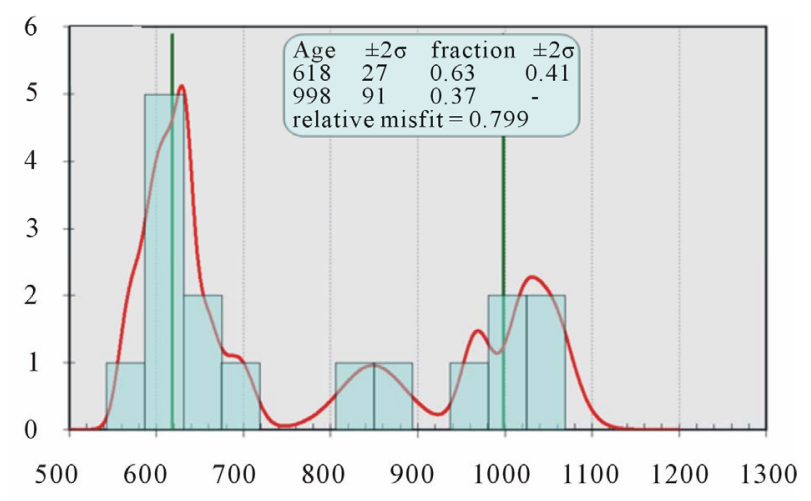

(a)

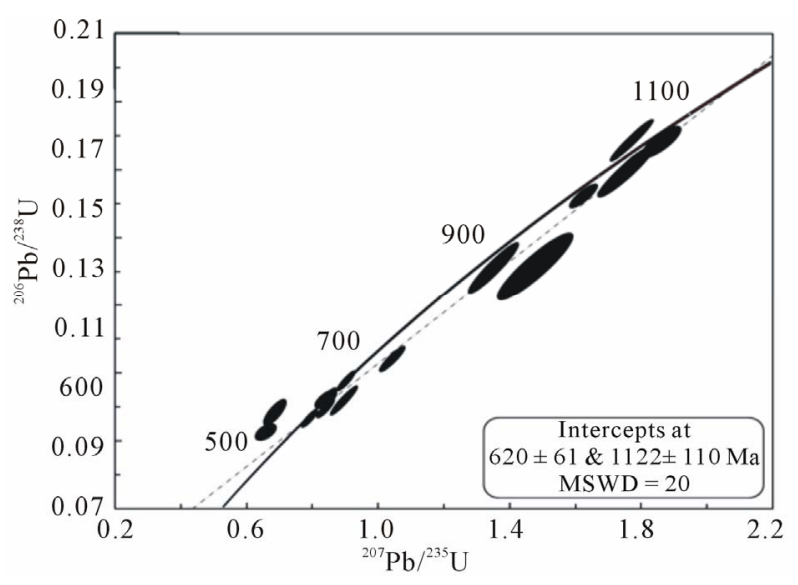

(b)

Figure 19. (a) Histogram showing the different thermal event recorded by no zoned from leucosomes in metapelite of the Yaoundé series; (b) U-Pb Discordia diagram ages for these zircons.

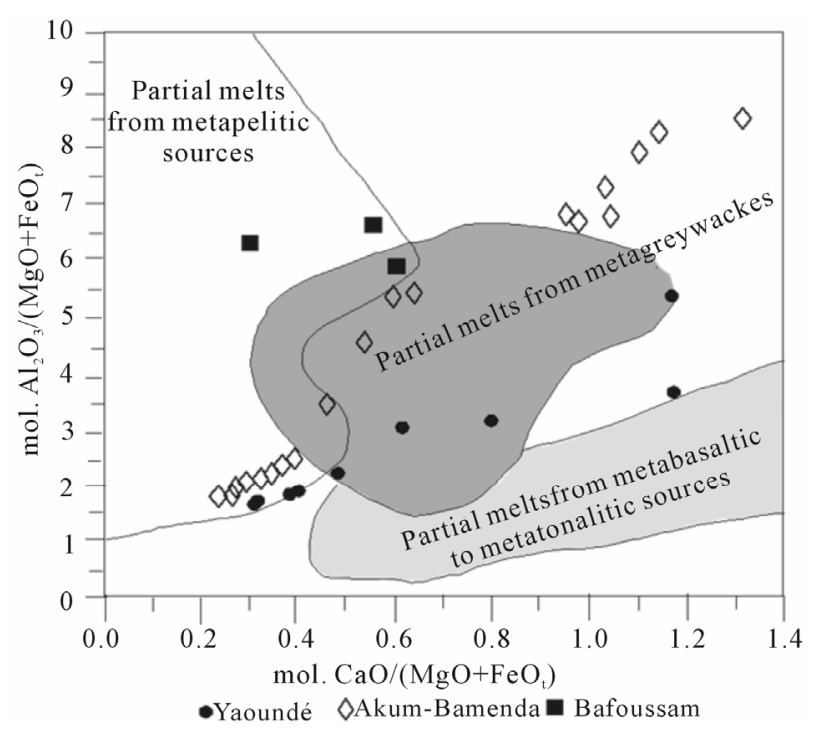

Figure 20. Molar $\mathrm{CaO} /(\mathrm{MgO}+\mathrm{FeOt})$ vs $\mathrm{Al}_{2} \mathrm{O}_{3} /(\mathrm{MgO}+$ FeOt) diagram showing the same sources for Yaoundé leucosomes, Akum-Bamenda leucogranites and two-micas granitoids of Bafoussam.

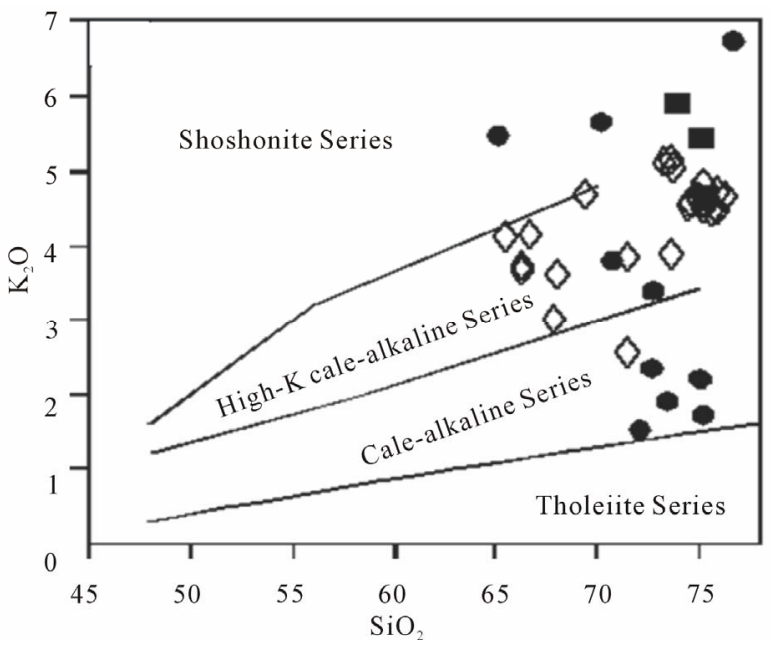

(a)

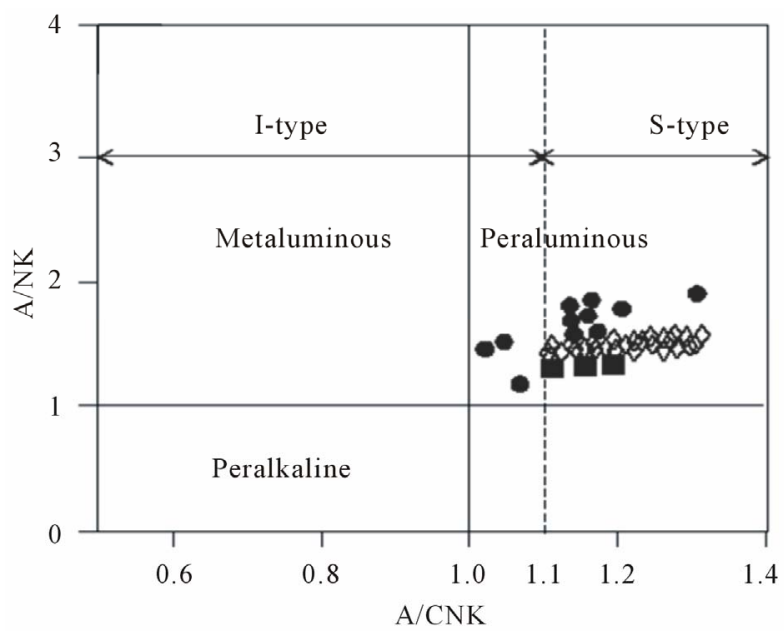

(b)

Figure 21. $\mathrm{SiO}_{2}$ vs $\mathrm{K}_{2} \mathrm{O}$ (a) and molar $\mathrm{A} / \mathrm{NK}$ vs $\mathrm{A} / \mathrm{CNK}$ (b) diagrams showing the same calc-alkaline, high-K to shoshonitic affinity, peraluminous character of the Yaoundé leucosomes, Akum-Bamenda leucogranites and two-micas granitoids of Bafoussam.

49].

The average $\mathrm{Sr}$ contents of Yaoundé leucosomes (218 $\mathrm{ppm}$ in in situ leucosomes, $410.63 \mathrm{ppm}$ in injected leucosomes) are closer to those of Akum-Bamenda leucogranites (307.39 ppm, Table 10), high-K calc-alkaline granitoids of Bapa-Batié (111 - 609 ppm) and Tonga (281 $780 \mathrm{ppm})$. The REE patterns of Yaoundé leucosomes and those of the granitoids of the central domain of the PANEFB are strongly parallel (Figure 22). These spectra show that the leucosomes of the Yaoundé series, as the other granitoids of the PANEFB, are strongly fractionated, with HREE depletion and LREE enrichment. However, the Yaoundé in situ leucosomes are more depleted in LREE and enriched in HREE than the AkumBamenda leucogranites and the two-mica granitoids of 
Table 10. Compared average chemical analyses of the Yaoundé leucosomes, Akum-Bamenda leucogranite and twomicas granitoids of Bafoussam.

\begin{tabular}{|c|c|c|c|c|}
\hline \multirow[b]{2}{*}{ Rocks } & \multicolumn{2}{|c|}{ Yaoundé leucosomes } & \multicolumn{2}{|c|}{ PANEFB Leucogranites } \\
\hline & In situ & Injected & $\begin{array}{l}\text { Akum-Bamenda } \\
\text { Leucogranites" }\end{array}$ & $\begin{array}{l}\text { Two-mica } \\
\text { ganitoids of } \\
\text { Bafoussam }\end{array}$ \\
\hline $\mathrm{SiO}_{2}$ & 74.41 & 71.96 & 71.17 & 73.10 \\
\hline $\mathrm{Al}_{2} \mathrm{O}_{3}$ & 12.29 & 15.59 & 15.81 & 14.47 \\
\hline $\mathrm{Fe}_{2} \mathrm{O}_{3}$ & 3.59 & 1.15 & 2.43 & 1.44 \\
\hline $\mathrm{MnO}$ & 0.06 & 0.02 & 0.04 & 0.04 \\
\hline $\mathrm{MgO}$ & 1.59 & 0.38 & 0.51 & 0.22 \\
\hline $\mathrm{CaO}$ & 1.86 & 2.12 & 1.07 & 0.67 \\
\hline $\mathrm{Na}_{2} \mathrm{O}$ & 2.92 & 3.57 & 3.87 & 3.29 \\
\hline $\mathrm{K}_{2} \mathrm{O}$ & 1.69 & 3.99 & 4.21 & 5.09 \\
\hline $\mathrm{TiO}_{2}$ & 0.53 & 0.27 & 0.29 & 0.17 \\
\hline $\mathrm{P}_{2} \mathrm{O}_{5}$ & 0.01 & 0.00 & 0.09 & 0.10 \\
\hline LOI & 0.66 & 0.53 & 0.55 & 0.84 \\
\hline $\mathrm{Rb}$ & 43.33 & 79.63 & 201.38 & 385.67 \\
\hline $\mathrm{Sr}$ & 218.00 & 410.63 & 307.39 & 86.00 \\
\hline $\mathrm{Zr}$ & 124.67 & 78.75 & 201.34 & 104.33 \\
\hline $\mathrm{Nb}$ & 3.67 & 0.63 & 27.22 & 24.33 \\
\hline Y & 20.83 & 12.50 & 48.41 & 13.33 \\
\hline $\mathrm{La}$ & 16.36 & 24.60 & 29.99 & 44.87 \\
\hline $\mathrm{Ce}$ & 33.18 & 48.37 & 60.79 & 77.60 \\
\hline $\mathrm{Nd}$ & 15.46 & 22.51 & 24.44 & 30.22 \\
\hline $\mathrm{Sm}$ & 3.67 & 4.52 & 4.34 & 5.51 \\
\hline $\mathrm{Eu}$ & 1.61 & 1.86 & 1.12 & 0.48 \\
\hline Gd & 3.28 & 3.46 & 4.02 & 3.72 \\
\hline Dy & 2.95 & 1.80 & 2.68 & 2.36 \\
\hline $\mathrm{Er}$ & 1.72 & 0.48 & 1.28 & 1.00 \\
\hline $\mathrm{Yb}$ & 1.88 & 0.38 & 1.01 & 0.98 \\
\hline $\mathrm{Lu}$ & 0.30 & 0.08 & 0.14 & 0.14 \\
\hline $\mathrm{K} / \mathrm{Rb}$ & 157.67 & 480.13 & 209.26 & 131.98 \\
\hline $\mathrm{Rb} / \mathrm{Sr}$ & 0.13 & 0.21 & 0.83 & 4.48 \\
\hline $\mathrm{Ca} / \mathrm{Sr}$ & 35.26 & 36.69 & 34.65 & 77.52 \\
\hline$(\mathrm{Ce} / \mathrm{Sm}) \mathrm{N}$ & 2.14 & 3.19 & 3.31 & 3.32 \\
\hline$(\mathrm{Gd} / \mathrm{Yb}) \mathrm{N}$ & 1.43 & 7.37 & 3.21 & 3.04 \\
\hline$(\mathrm{Ce} / \mathrm{Yb}) \mathrm{N}$ & 4.74 & 36.42 & 15.43 & 20.20 \\
\hline $\mathrm{Eu} / \mathrm{Eu}^{*}$ & 1.45 & 4.24 & 0.83 & 0.33 \\
\hline
\end{tabular}

*Average of whole rock analyses of [4]; ${ }^{* *}$ Average of whole rock analyses of [21].

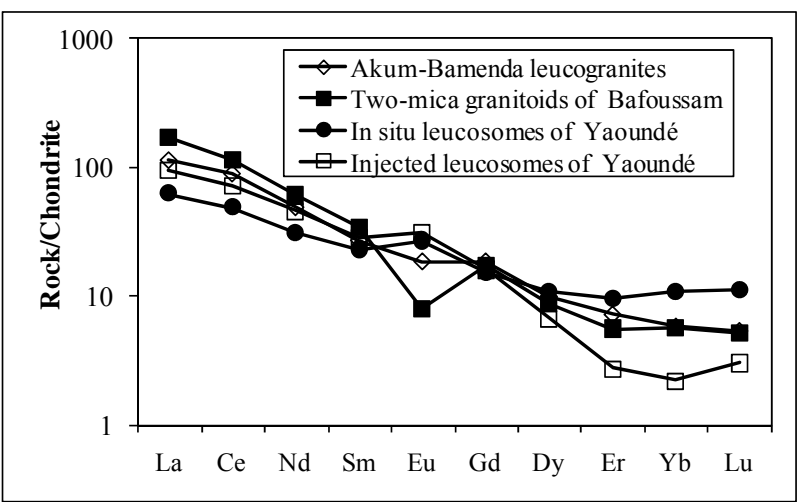

Figure 22. Chondrite-normalized REE comparison patterns for the Yaoundé leucosomes, Akum-Bamenda leucogranites and two-micas granitoids of Bafoussam.

Bafoussam. The REE patterns also show positive Eu anomalies for the Yaoundé leucosomes and negative to null $\mathrm{Eu}$ anomalies for the Akum-Bamenda leucogranites and the two-mica granitoids of Bafoussam. This contrasting Eu behaviour can be attributed to the difference in the geodynamic setting (tectono-metamorphic context in Yaoundé and tectono-magmatic context in the other domain of the PANEFB) of the emplacement of these granitoids.

\subsection{Uniqueness of the Melting/Magmatism during the Pan-African Orogeny}

The Palaeoproterozoic protolith $(2127 \mathrm{Ma})$ of Yaoundé series underwent metamorphism between 1122 and 911 Ma. The Nd isotopic signature confirms the presence of late Paleoproterozoic to Archean relics in the central domain of the PANEFB [3,19,20,64-66]. In the SE of Tibati-Banyo shear zone, Pan-African granitoids derived from melting of a Paleoproterozoic crust with low participation of juvenile magma $[3,18,62,66,67]$. These observations confirm the initial existence of Paleoproterozoic formations in the three domains of the PANEFB in Cameroon.

The melting or the magmatism responsible for the leucosomes emplacement in the Yaoundé series occurred between 658 and $620 \mathrm{Ma}$. This magmatism is contemporaneous:

1) In the central domain, with the emplacement of two-mica granitoids of Bafoussam (564 - $558 \mathrm{Ma}$, EMP age; [21]), high-K calc-alkaline granitoids of Bapa-Batié (619 - $600 \mathrm{Ma}, \mathrm{U}-\mathrm{Pb}$ age on zircon; [24]), and synkinematic granitoids of Tonga (618 Ma, U-Pb age on zircon; [19]);

2) In the northern domain, with the Pan-African (630 $\mathrm{Ma}, \mathrm{U}-\mathrm{Pb}$ age on zircon; [15]) calc-alkaline Syn- $\mathrm{D}_{2}$ plutonism (diorite, granodiorite and tonalite);

3) In the eastern Cameroon, with the continental 
magmatism responsible for the emplacement of PanAfrican (614 $\pm 41 \mathrm{Ma})$ peraluminous granite and diorite, orthogneisses at $621 \pm 13 \mathrm{Ma}$ [25]. These orthogneisses are very abundant at the Cameroon-Central African Republic boundary.

For the above observations, the following interpretations could be made:

1) The high-K calc-alkaline to shoshonitic affinity of granitoids is observed in both central domain [4,19,21, $22,24,63$ ], northern domain [15] and southern domain (as revealed by this work) of the PANEFB. With the ubiquity of the high-K calc-alkaline affinity in the PANEFB, we suggest that a former crust, widespread from the south to the north, was involved in the genesis of these rocks as outlined in $[3,5,6]$;

2) The generalization of magmatism or melting in the whole PANEFB during the Pan-African orogeny between 592 and $658 \mathrm{Ma}$;

3) The existence of two sources (metapelite and metagreywacke sources) for the peraluminous granitoids of the PANEFB.

All these interpretations allow us to propose, in addition to metamorphism and tectonics, the existence of a unique magmatic event along the entire PANEFB in Cameroon.

\section{Conclusions}

The main conclusions obtained from this study are the following:

1) The Yaoundé series is composed of metasediment and metabasite which have been metamorphosed during Tonien-Stenien (911 - $1127 \mathrm{Ma}$ ) period.

2) These rocks have been affected by a melting responsible for the S-type and I-type peraluminous leucosomes emplacement. These leucosomes are calc-alkaline, high-K to shoshonitic affinity similar to the other granitoids of the PANEFB.

3) Geochemical data reveal that in situ leucosomes derived from the melting of the host metapelite whereas injected leucosomes derived from the melting of metagreywacke. These sources are similar to those of granitoids from central and northern domains of the PANEFB.

4) The melting responsible for the genesis of leucosomes in the Yaoundé series took place between 592 and $658 \mathrm{Ma}$ as the magmatism responsible for the emplacement of granitoids in the other domains the PANEFB.

5) There is therefore uniqueness of melting and magmatism all over the PANEFB as the uniqueness observed in metamorphic and tectonic aspects.

\section{Acknowledgements}

The authors thank the Institute für Minerologie of University of Freiberg (Germany) and the Laboratory of
Geochronology of the University of Brasilia (Brazil) for providing many facilities for EMP monazite dating and LA-ICP-MS U-Pb dating respectively. This is a contribution to IGCP project 616 .

\section{REFERENCES}

[1] M. Pichavent, D. J. Kontak, L. Briqueu, J. V. Herrera and A. H. Clark, "The Miocene-Pliocene Macusani Volcanic, SE Peru. II. Geochemistry and Origin of a Peraluminous Magma," Contribution to Mineralogy and Petrology, Vol. 100, No. 3, 1988, pp. 325-338.

[2] M. Pichavent, D. J. Kontak, J. V. Herrera and A. H. Clark, "The Miocene-Pliocene Macusani Volcanic, SE Peru I. Mineralogy and Magmatic Evolution of a Two Mica Aluminosilicate Bearing Ignimbrite Suite," Contribution to Mineralogy and Petrology, Vol. 100, No. 3, 1988, pp. 300-324.

[3] J. P. Nzenti, E. L. T. Njiosseu and A. N. Nchare, "The Metamorphic Evolution of the Palaeoproterozoic High Grade Banyo Gneisses (Adamawa, Cameroon, Central Africa)," Journal of the Cameroon Academy of Sciences, Vol. 7, No. 2, 2007, pp. 95-109.

[4] J. P. Nzenti, B. Abaga, C. E. Suh and C. Nzolang, "Petrogenesis of Peraluminous Magmas from the AkumBamenda Massif, Pan-African Fold Belt, Cameroon," International Geology Review, Vol. 53, No. 10, 2011, pp. 1121-1149. doi:10.1080/00206810903442402

[5] D. T. Tchato, B. Schulz and J. P. Nzenti, "Electron Microprobe (EMP) Monazite Dating and P-T Data of the Neoproterozoic Metamorphic and Mylonitic Events in the Kekem Area, Cameroon North Equatorial Fold Belt," Neues Jahbur of Paleontology, Vol. 186, No. 1, 2009, pp. 95-109.

[6] J. P. Nzenti, P. Barbey, J. Macaudiere and D. Soba, "Origin and Evolution of the Late Precambrian High-Grade Yaoundé Gneisses (Cameroon)," Precambrian Research, Vol. 38, No. 2, 1988, pp. 91-109. doi:10.1016/0301-9268(88)90086-1

[7] T. Ngnotué, J. P. Nzenti, P. Barbey and F. M. Tchoua, "The Ntui-Betamba High Grade Gneisse: A Northward Extension of the Pan-African Yaoundé Gneisses in Cameroon," Journal of African Earth Sciences, Vol. 31, No. 2, 2000, pp. 369-381.

[8] J. P. Nzenti, P. Barbey, P. Jegouzo and C. Moreau, "Un Nouvel Exemple de Ceinture Granulitique dans une Chaîne Protérozoïque de Transition: Les Migmatites de Yaoundé au Cameroun," Compte Rendu Académie des Sciences de Paris, Vol. 299, No. 17, 1984, pp. 1197-1199.

[9] J. Penaye, S. F. Toteu, W. R. Van Schmus and J. P. Nzenti, "U-Pb and Sm-Nd Preliminary Geochronology Data on the Yaoundé Series, Cameroon: Re-Interpretation of the Granulitic Rocks as the Suture of Collision in the 'Centrafrican' Belt," Comptes Rendus de l'Académie des Sciences de Paris, Vol. 317, No. 2, 1993, pp. 789-794.

[10] S. F. Toteu, W. R. Van Schmus, J. Penaye and J. B. Nyobe, "U-Pb and Sm-Nd Evidence of Eburnian and Pan-African High Grade Metamorphism in Cratonic 
Rocks of Southern Cameroon," Precambrian Research, Vol. 67, No. 3-4, 1994, pp. 321-347. doi:10.1016/0301-9268(94)90014-0

[11] S. Owona, B. Schulz, L. Ratschbacher, J. M. Ondoa, G. E. Ekodeck, F. M. Tchoua and P. Affaton, "Pan-African Metamorphic Evolution in the Southern Yaoundé Group (Oubanguide Complex, Cameroon) as Revealed by EMP Monazite Dating and Thermobarometry of Garnet Metapelites," Journal of African Earth Sciences, Vol. 59, No. 1, 2010, pp. 125-139. doi:10.1016/i.jafrearsci.2010.09.003

[12] J. P. Nzenti, "Pétrogenèse des Migmatites de Yaoundé (Cameroun): Eléments pour un Modèle Géodynamique de la Chaîne Panafricaine Nord-Equatoriale," These Doctorat, University of Nancy I, Nancy, 1987.

[13] P. Barbey, J. Macaudière and J. P. Nzenti, "High-Pressure Dehydration Melting of Metapelites: Evidence from Migmatites of Yaoundé (Cameroon)," Journal of Petrology, Vol. 31, No. 2, 1990, pp. 401-428.

[14] V. Ngako, "Evolution Métamorphique et Structurale de la Bordure Sud-Ouest de la 'Série de Poli', Segment Camerounais de la Chaîne Panafricaine," Mémoire et documents du C.A.E.S.S., Vol. 5, 1986, 185 p.

[15] S. F. Toteu, A. Michard, J. M. Bertrand and G. Rocci " $\mathrm{U} / \mathrm{Pb}$ of Precambrian Rocks from Northern Cameroon, Orogenic Evolution and Chronology of the Pan-African Belt of Central Africa," Precambrian Research, Vol. 37, No. 1, 1987, pp. 71-87. doi:10.1016/0301-9268(87)90040-4

[16] J. Penaye, S. F. Toteu, A. Michard, J. M. Bertrand and D. Dautel, "Reliques Granulitiques d'Age Protérozoïque Inférieur dans la Zone Mobile Panafricaine d'Afrique Centrale au Cameroun: Géochronologie U-Pb sur Zircons," Comptes Rendus de l'Académie des Sciences de Paris, Vol. 309, No. 2A, 1989, pp. 315-318.

[17] J. P. Nzenti, "Prograde and Retrograde Garnet Zoning at High Pressure and Temperature in Metapelitic and Grenatite Rocks from Yaoundé," Journal of African Earth Sciences, Vol. 15, No. 1, 1992, pp. 73-79. doi:10.1016/0899-5362(92)90008-Z

[18] J. P. Nzenti, P. Barbey and F. M. Tchoua, "Evolution Crustale au Cameroun: Eléments pour un Modèle Géodynamique de l'Orogenèse Néoprotérozoïque," In: J.-P. Vicat and P. Bilong, Eds., Géologie et Environments au Cameroun, GEOCAM, Vol. 2, 1999, pp. 397-407.

[19] E. L. T. Njiosseu, J. P. Nzenti, T. Njanko, B. Kapajika and A. Nédelec, "New U-Pb Zircon Ages from Tonga (Cameroon): Coexisting Eburnean-Transamazonian (2.1 Ga) and Pan-African (0.6 Ga) Imprints,"Comptes Rendus Géosciences, Vol. 337, No. 16, 2005, pp. 551-562. doi:10.1016/j.crte.2005.02.005

[20] A. A. Ganwa, W. Frisch, W. Siebel, G. E. Ekodeck, C. K. Shang and V. Ngako, "Archean Inheritances in the Pyroxene-Amphibole-Bearing Gneiss of the Méiganga Area (Central North Cameroon): Geochemical and $\mathrm{Pb} / \mathrm{Pb}$ Age Imprints," Comptes Rendus Geosciences, Vol. 340, No. 4, 2008, pp. 211-222. doi:10.1016/j.crte.2007.12.009

[21] M. L. Djouka-Fonkwe, B. Schulz, J. P. Tchouankoué and C. Nzolang, "Geochemistry of the Bafoussam Pan-Afri- can I- and S-type Granitoids in Western Cameroon," Journal of African Earth Sciences, Vol. 50, No. 2-3, 2008, pp. 148-167. doi:10.1016/i.jafrearsci.2007.09.015

[22] G. D. K. Nono, J. P. Nzenti, C. E. Suh and S. Ganno, "Geochemistry of Ferriferous, High-K Calc-Alkaline Granitoids from Banefo-Mvoutsaha Massif (NE Bafoussam), Central Domain of the Pan-African Fold Belt, Cameroon," The Open Geology Journal, Vol. 4, No. 1, 2010, pp. 21-34.

[23] A. N. Nchare, J. P. Nzenti, E. L. T. Njiosseu S. Ganno and T. Ngnotué, "Synkinematic Ferro-Potassic Magmatism from the Mekwene-Njimafofire Foumban Massif, along the Foumban-Banyo Shear Zone in Central Domain of Cameroon Pan-African Fold Belt," Journal of Geology and Mining Research, Vol. 2, No. 6, 2010, pp. 142-158.

[24] C. Chebeu, C. D. N. Nlend, J. P. Nzenti and S. Ganno, "Neoproterozoic High-K Calc-Alkaline Granitoids from Bapa-Batié, North Equatorial Fold Belt, Central Cameroon: Petrogenesis and Geodynamic Significance," The Open Geology Journal, Vol. 5, 2011, pp. 1-20. doi: 10.2174/1874262901105010001

[25] D. Soba, A. Michard, S. F. Toteu, D. I. Norman, J. Penaye, V. Ngako, J. P. Nzenti and D. Dautel, "Données Géochronologiques Nouvelles (Rb-Sr, U-Pb et $\mathrm{Sm}-\mathrm{Nd}$ ) sur la Zone Mobile Panafricaine de l'Est-Cameroun: Age Protérozoique Supérieur de la Série de Lom," Comptes Rendus de l'Académie des Sciences de Paris, Vol. 312, No. 2, 1991, pp. 1453-1458.

[26] G. Njiekak, W. Dörr, J. P. Tchouankoue and G. Zulauf, "U-Pb Zircon and Microfabric Data of (Meta) Granitoids of Western Cameroon: Constraints on the Timing of Pluton Emplacement and Deformation in the Pan-African Belt of Central Africa," Lithos, Vol. 102, No. 3-4, 2008 , pp. 460-477. doi:10.1016/j.lithos.2007.07.020

[27] K. Govindaraju and R. Montanary, "Routine Performance of a Matrix-Correction Free X-Ray Flurorescence Spectrometric Method for Rock Analysis," X-ray Spectrometry, Vol. 7, No. 3, 1978, pp. 148-151. doi: $10.1002 /$ xrs. 1300070307

[28] K. Govindaraju, "Report (1980) on Three GIT-IWG Rock Reference Samples: Anorthosite from Greenland, AN-G; Basalte d'Essey-la-Cote, BE-N; Granite de Beauvoir, MA-N," Geostandards Newsletters, Vol. 4, No. 1, 1980, pp. 49-138. doi:10.1111/j.1751-908X.1980.tb00274.X

[29] B. M. Jahn, P. Vidal and G. R. Tilton, "Archean Mantle Heterogeneity: Evidence from Chemical and Isotopic Abundances in Archean Igneous Rocks," Philosophical Transactions of the Royal Society, Vol. 297, 1980, pp. 353-364. doi:10.1098/rsta.1980.0221

[30] B. Schulz, H. Brätz, K. Bombach and E. Krenn, "In situ $\mathrm{Th}-\mathrm{Pb}$ Dating of Monazite by $266 \mathrm{~nm}$ Laser Ablation and ICP-MS with a Single Collector, and Its Control by EMP Analysis-Z. Angew," Geology, Vol. 35, No. 4, 2007, pp. 377-392.

[31] E. Jarosewich and L. A. Boatner, "Rare-Earth Element Reference Samples for Electron Microprobe Analysis," Geostandards Newsletter, Vol. 15, No. 2, 1991, pp. 397399. doi:10.1111/j.1751-908X.1991.tb00115.x

[32] J. J. Donovan, J. M. Hanchar, P. M. Picolli, M. D. Schrier, 
L. A. Boatner and E. Jarosewich, "A Re-Examination of the Rare-Earth-Element Orthophosphate Standards in Use for Electron-Microprobe Analysis," Canadian Mineralogist, Vol. 41, No. 1, 2003, pp. 221-232. doi:10.2113/gscanmin.41.1.221

[33] F. Finger and H. M. Helmy, "Composition and Total-Pb Model Ages of Monazite High Grade Paragneisses in the Abu Swayel Area, Southern Eastern Desert, Egypt," Mineralogy and Petrology, Vol. 62, No. 3-4, 1998, pp. 269289. doi:10.1007/BF01178032

[34] J. M. Montel, S. Foret, M. Veschambre, C. Nicollet and A. Provost, "A Fast, Reliable, Inexpensive in-Situ Dating Technique: Electron Microprobe Ages of Monazite," Chemical Geology, Vol. 131, No. 1, 1996, pp. 37-53. doi:10.1016/0009-2541(96)00024-1

[35] M. J. Jercinovic and M. L. Williams, "Analytical Perils (and Progress) in Electron Microprobe Trace Element Analysis Applied to Geochronology: Background Acquisition, Interferences, and Beam Irradiation Effects," American Mineralogist, Vol. 90, No. 5, 2005, pp. 526546. doi:10.2138/am.2005.1422

[36] B. Buhn, M. M. Pimentel, M. Matteini and E. L. Dantas, "High Spatial Resolution Analysis of $\mathrm{Pb}$ and $\mathrm{U}$ Isotopes for Geochronology by Laser Ablation Multi-Collector Inductively Coupled Plasma Mass Spectrometry (LA-MCICP-MS)," Anais da Academia Brasiliera de Ciências, Vol. 81, No. 1, 2009, pp. 1-16. doi:10.1590/S0001-37652009000100011

[37] S. E. Jackson, N. J. Pearson and W. L. Griffin, "The Application of Laser Ablation-Inductively Coupled PlasmaMass Spectrometry to in Situ U-Pb Zircon Geochronology," Chemical Geology, Vol. 211, No. 1-2, 2004, pp. 47-69. doi:10.1016/j.chemgeo.2004.06.017

[38] F. Albarède, P. Telouk, J. Blichert-Toft, M. Boyet, A. Agranier and B. Nelson, "Precise and Accurate Isotopic Measurements Using Multiple Collector ICPMS," Geochimical and Cosmochimical Acta, Vol. 68, No. 12, 2004, pp. 2725-2744. doi:10.1016/j.gca.2003.11.024

[39] L. P. Black, S. L. Kamo, C. M. Allen, D. W. Davis, J. N. Aleinikoff, J. W. Valley, R. Mundil, I. H. Campbell, R. J. Korsch, I. S. William and C. Foudoulis, "Improved ${ }^{206} \mathrm{~Pb} /{ }^{238} \mathrm{U}$ Microprobe Geochronology by the Monitoring of a Trace-Element-Related Matrix Effect: SHRIMP, ID-TIMS, LA-ICP-MS and Oxygen Isotope Documentation for a Series of Zircon Standards," Chemical Geology, Vol. 205, No. 1-2, 2004, pp. 115-140. doi:10.1016/j.chemgeo.2004.01.003

[40] J. S. Stacey and J. D. Kramers, "Approximation of Terrestrial Lead Isotope Evolution by a Two-Stage Mode," Earth Planetary Science Letters, Vol. 26, No. 2, 1975, pp. 207-221. doi:10.1016/0012-821X(75)90088-6

[41] K. R. Ludwig, "Users Manual for Isoplot/Ex rev. 2.49. A Geochronological Toolkit for Microsoft Excel," Berkeley Geochronology Center Special Publication, Vol. 1a, 2001, pp. 1-55.

[42] K. R. Ludwig, "User's Manual for Isoplot/Ex v. 3.00. A Geochronological Toolkit for Microsoft Excel," $B G C$ Special Publication, Vol. 4, No. 1, 2003, pp. 1-71.

[43] E. A. K. Middlemost, "Magmas and Magmatic Rocks,"
Longman, London, 1985.

[44] J. M. Bertrand, C. Dupuy, J. Dostal and I. Davidson, "Geochemistry and Geotectonic Interpretation of Granitoids from Central Iforas (Mali, West Africa)," Precambrian Research, Vol. 26, No. 3-4, 1984, pp. 265-283. doi:10.1016/0301-9268(84)90004-4

[45] R. Ayuso and J. G. Arth, "The Northeast Kingdom Batholiths, Vermon: Magmatic evolution and Geochemical Constraints on the Origin of Acadian Granitics Rocks," Contribution to Mineralogy and Petrology, Vol. 111, No. 1, 1992, pp. 1-23. doi:10.1007/BF00296574

[46] K. Suzuki, M. Adachi and I. Kajisuka, "Electron Microprobe Observations of $\mathrm{Pb}$ Diffusion in Metamorphosed Detrital Monazites," Earth and Planetary Sciences Letters, Vol. 128, No. 3-4, 1994, pp. 391-405. doi:10.1016/0012-821X(94)90158-9

[47] M. P. Searle, R. R. Parrish, K. V. Hodges, A. Hurford, M. W. Ayres and M. J. Whitehouse, "Shisha Pangma Leucogranite, South Tibetan Himalayan: Field Relations, Geochemistry, Age, Origin and Emplacement," Journal of Geology, Vol. 105, No. 3, 1997, pp. 295-317. doi: $10.1086 / 515924$

[48] B. Barbarin, "A Review of the Relationships between Granitoids Types, Their Origin and Their Geodynamics Environments," Lithos, Vol. 46, No. 4, 1999, pp. 605626. doi:10.1016/S0024-4937(98)00085-1

[49] P. I. Nabalek and M. Liu, "Petrology and Thermal Constraints on the Origin of Leucogranites in Collisional Orogens," Transactions of the Royal Society of Edinburgh, Earth Sciences, Vol. 95, No. 1, 2004, pp. 73-85. doi:10.1017/S0263593304000094

[50] C. F. Miller, "Are Strongly Peraluminous Magmas Derived from Pelitic Sedimentary Sources?" Journal of Geology, Vol. 93, No. 6, 1985, pp. 673-689. doi: $10.1086 / 628995$

[51] A. E. P. Douce, "Experimental Generation of Hybrid Silicic Melts by Reaction of High Al Basalt with Metamorphic Rocks," Journal of Geophysical Research, Vol. 100, No. B8, 1995, pp. 623-639.

[52] P. Le Fort, M. Cuney, C. Deniel, C. France-Lanord, S. M. F. Sheppard, B. N. Upreti and P. Vidal, "Crustal Generation of the Himalayan Leucogranites," Tectonophysics, Vol. 134, No. 1, 1987, pp. 39-57. doi:10.1016/0040-1951(87)90248-4

[53] A. J. R. White and B. W. Chappell, "A-Type Granites: Geochemical Characteristics, Discrimination and Petrogenesis," Contribution to Mineralogy and Petrology, Vol. 95, No. 4, 1987, pp. 407-419. doi:10.1007/BF00402202

[54] N. B. W. Harris and S. Inger, "Trace Element Modelling of Pelitte-Derived Granites," Contributions to Mineralogy and Petrology, Vol. 110, No. 1, 1992, pp. 46-56. doi:10.1007/BF00310881

[55] B. J. Williamson, H. Downes, M. F. Thirlwall and A. Beard, "Geochemical Constraints on Restite Composition and Unmixing in the Velay Anatectic Granite, French Massif Central," Lithos, Vol. 40, No. 2-4, 1997, pp. $295-$ 319. doi:10.1016/S0024-4937(97)00033-9

[56] M. Cuney, P. Sabaté, P. Vidal, M. Marinho and H. Com- 
ceiçao, "The 2 Ga Peraluminous Magmatism of Jacobina-Contendas Mirante Belt (Bahia-Brasil): Major- and Trace-Element Geochemistry and Metallogenic Potential," Journal of Volcanology and Geothermal Research, Vol. 44, No. 1-2, 1990, pp. 123-141. doi:10.1016/0377-0273(90)90015-8

[57] D. Vielzeuf and J. Hollaway, "Experimental Determination of the Fluid-Absent Melting Relations in the Pelitic System," Contribution to Mineralogy and Petrology, Vol. 98, No. 3, 1988, pp. 257-276. doi:10.1007/BF00375178

[58] A. E. P. Douce and A. D. Johnston, "Phase Equilibria and Melt Productivity in the Politic System: Implications for the Origin of Peraluminous Granitoids and Aluminous Granulites," Contribution to Mineralogy and Petrology, Vol. 107, No. 2, 1991, pp. 202-218. doi:10.1007/BF00310707

[59] B. R. Frost, C. G. Barnes, W. J. Collins, R. J. Arculus, D. J. Ellis and C. D. Frost, "A Geochemical Classification for Granitic Rocks," Journal of Petrology, Vol. 42, No. 11, 2001, pp. 2033-2048. doi:10.1093/petrology/42.11.2033

[60] F. F. Altherr, A. Holl, E. Hegner, C. Langer and H. Kreuser, "High-Potassium, Calc-Alcaline I-Type Plutonism in the European Variscides: Nothern Vosges (France) and Northern Schwarzwald (Germany)," Lithos, Vol. 50, No. 1-3, 2000, pp. 51-73. doi:10.1016/S0024-4937(99)00052-3

[61] C. Nzolang, H. Kagami, J. P. Nzenti and F. Holz, "Geochemistry and Preliminary Sr-Nd Isotopic Data on the Neoproterozoic Granitoids from the Bantoum Area, West Cameroon: Evidence for a Derivation from a Paleoproterozoic to Archean Crust," Polar Geoscience, Vol. 16, 2003, pp. 196-226.

[62] T. Njanko, A. Nedélec and P. Affaton, "Synkinematic
High-K Calc-Alkaline Plutons Associated to the Pan-African Central Cameroon Shear Zone (West-Tibati area): Petrology and Geodynamic Significance," Journal of African Earth Sciences, Vol. 44, No. 4-5, 2006, pp. 494 510. doi:10.1016/j.jafrearsci.2005.11.016

[63] J. P. Nzenti, B. Kapajika, G. Wörner and R. T. Lubala, "Synkinematic Emplacement of Granitoids in a Pan-African Shear Zone in Central Cameroon," Journal of African Earth Sciences, Vol. 45, No. 1, 2006, pp. 74-86. doi:10.1016/j.jafrearsci.2006.01.005

[64] J. P. Nzenti, P. Barbey, J. M. Bertrand and J. Macaudière, "La Chaîne Panafricaine au Cameroun: Cherchons Suture et Modèle!" 15th Réunion des Sciences de la Terre, Nancy, 26-28 April 1994.

[65] A. A. Ganwa, W. Frisch, W. Siebel, G. E. Ekodeck, C. K. Shang, J. M. Ondoa, M. Satir and J. T. Numbem, "Zircon $\mathrm{Pb} / \mathrm{Pb}$ Evaporation Ages of Panafrican Metasedimentary Rocks in the Kombé-II Area (Bafia Group, Cameroon): Constraints on Protolith Age and Provenance," Journal of African Earth Sciences, Vol. 51, No. 2, 2008, pp. 77-88. doi:10.1016/j.jafrearsci.2007.12.003

[66] A. A. Ganwa, W. Siebel, C. K. Shang, N. Seguem and G. E. Ekodeck, "New Constraints from Pb-Evaporation Zircon Ages of the Méiganga Amphibole-Biotite Gneiss, Central Cameroon, on Proterozoic Crustal Evolution," International Journal of Geosciences, Vol. 2, No. 2, 2011, pp. 138-147.

[67] J. P. Nzenti, "Neoproterozoic Alkaline Meta-Ignous Rocks from the Pan-African North Equatorial Fold Belt (Yaoundé, Cameroon): Biotitites and Magnetite Rich Pyroxenites," Journal of African Earth Sciences, Vol. 26, No. 1, 1998, pp. 37-47. doi:10.1016/S0899-5362(97)00135-8 